\title{
Mechanisms of hyperprogressive disease after immune checkpoint inhibitor therapy: what we (don't) know
}

\author{
Simone Camelliti ${ }^{1}$, Valentino Le Noci ${ }^{1}$, Francesca Bianchi ${ }^{2}$, Claudia Moscheni ${ }^{1}$, Francesca Arnaboldi ${ }^{1}$, \\ Nicoletta Gagliano ${ }^{1}$, Andrea Balsari ${ }^{1}$, Marina Chiara Garassino ${ }^{3}$, Elda Tagliabue ${ }^{2}$, Lucia Sfondrini ${ }^{1}$ and \\ Michele Sommariva ${ }^{1 *}$ (i)
}

\begin{abstract}
Immune checkpoint inhibitors (ICls) have made a breakthrough in the treatment of different types of tumors, leading to improvement in survival, even in patients with advanced cancers. Despite the good clinical results, a certain percentage of patients do not respond to this kind of immunotherapy. In addition, in a fraction of nonresponder patients, which can vary from 4 to $29 \%$ according to different studies, a paradoxical boost in tumor growth after $\mathrm{ICl}$ administration was observed: a completely unpredictable novel pattern of cancer progression defined as hyperprogressive disease. Since this clinical phenomenon has only been recently described, a universally accepted clinical definition is lacking, and major efforts have been made to uncover the biological bases underlying hyperprogressive disease. The lines of research pursued so far have focused their attention on the study of the immune tumor microenvironment or on the analysis of intrinsic genomic characteristics of cancer cells producing data that allowed us to formulate several hypotheses to explain this detrimental effect related to ICI therapy. The aim of this review is to summarize the most important works that, to date, provide important insights that are useful in understanding the mechanistic causes of hyperprogressive disease.
\end{abstract}

Keywords: Hyperprogressive disease, Immune checkpoint inhibitors, Immunotherapy, Immune-mediated mechanisms

\section{Background}

Immune checkpoints and immune checkpoint blockade: a brief overview

Immune checkpoints (ICs), such as cytotoxic T lymphocyte-associated protein 4 (CTLA-4), programmed cell death protein 1 (PD-1) and programmed cell death ligand 1 and 2 (PD-L1 and -L2), belong to complex regulation systems that are physiologically involved in fine tuning the immune response and in the prevention of autoimmune reactions [1]. However, the same

\footnotetext{
* Correspondence: michele.sommariva@unimi.it

'Dipartimento di Scienze Biomediche per la Salute, Università degli Studi di Milano, via Mangiagalli 31, 20133 Milan, Italy

Full list of author information is available at the end of the article
}

mechanisms can be exploited by cancer cells to elude immune system attack [2]. Indeed, it is well known that the upregulation of these molecules in immune cells infiltrating the tumor microenvironment (TME) or on cancer cells themselves can lead to immune escape and, therefore, to poor prognosis [3]. Blockade of ICs by specific antibodies (immune checkpoint inhibitors, ICIs) determines a sort of "awakening" of antitumor immunity and represents an excellent and novel therapeutic strategy in the oncology field [4]. Several clinical studies have demonstrated the efficacy of these therapeutic approaches compared with conventional therapies. Response rates following ICI therapy (anti-CTLA4 or antiPD-1/PD-L1 antibody therapy) were observed in 13.3 to 
$44 \%$ of patients with head and neck squamous cell carcinoma (HNSCC) [5], advanced melanoma [6-11], nonsmall cell lung cancer [12-14], renal cell carcinoma [15, 16], Merkel cell carcinoma [17] and metastatic urothelial carcinoma [18]. Notably, a recently published retrospective cross-sectional study, performed considering the highest response rate to ICI treatment for all tumor types, estimated that in 2018, the percentage of US cancer patients who received benefit from IC blockade was $12.46 \%$ [19]. These data indicate that most patients do not respond properly to therapy and progress despite treatment. The reasons for such a lack of benefit can be ascribed to different causes that can be grouped into two broad areas, defined as primary and acquired resistance mechanisms $[20,21]$. The former, where certain characteristics of cancer cells/TME prevent ICIs from being efficacious and, therefore, patients do not respond to immunotherapy, can be determined by the lack of tumor antigenic mutations or defective antigen presentation, constitutive PD-L1 expression, impaired T cell tumor infiltration and function and an increased presence of immune suppressive cells within the tumor microenvironment TME [20, 21]. The latter, which occurs in patients who, after exhibiting an initial response to immunotherapy, eventually relapse and progress, includes phenomena such as aberrant activation of Janus kinases 1 and 2 (JAK1/2), leading to impaired sensitivity to IFN- $\gamma$ produced by activated T cells and upregulation of alternative coinhibitory immune checkpoints [20,21].

\section{Hyperprogressive disease (HPD): an unexpected outcome to ICI therapy}

Moreover, among the nonresponders, it is possible to identify a population of patients, whose percentage can vary from 4 to $29 \%$ according to different studies [22], who experience an extremely rapid increase in tumor growth and metastatic spread after ICI administration, a dramatic progression of disease that, for this reason, was called hyperprogressive disease (HPD). It is worth mentioning that HPD represents a completely different pattern of progression and is not superimposable with conventional progressive disease or pseudoprogression. One of the first clues about the existence of HDP was provided by the observations made by Chubachi et al., who described a patient with non-small cell lung cancer (NSCLC) characterized by an acceleration in tumor growth during anti-PD-1 therapy, a phenomenon that the authors named "disease flare" [23]. In 2017, the work by Champiat et al. provided the first systematic description and a clear definition of HPD [24]. According to RECIST1.1 criteria, they classified HPD as those tumor progressions with a minimum two-fold increase in tumor growth rate (TGR) after initiation of therapy compared to the pretherapy TGR [24]. In this study, 218 patients with different types of cancers were treated with anti-PD1 or anti-PD-L1 antibody monotherapy. Among 131 patients evaluable for the analysis, 12 of them, representing $24 \%$ of patients diagnosed with disease progression, were classified as having HPD. Moreover, survival analysis demonstrated that compared to patients with complete or partial response, HPD patients were characterized by a 25.94 -fold increase in dying. Another important finding was that HPD was not restricted to a specific tumor histotype but involved a broad spectrum of cancers. The pioneering publication of Champiat et al. was then supported and corroborated by other clinical studies [25-31] (Table 1).

Since HPD was only recently brought to the attention of the scientific community, there are many aspects that need to be clarified and that still represent a matter of debate. First, there are no internationally accepted guidelines to identify HPD patients, and every single research group utilizes its own criteria based on radiological or clinical parameters. For example, the criteria described in [24] were made more stringent in a subsequent paper published by the same research group. Indeed, the authors defined HPD as a RECIST 1.1 progressive disease at first evaluation with a $\triangle \mathrm{TGR}$ (difference between TGR on therapy and TGR pretherapy) greater than 50\% [28]. Another example of radiological definition of HPD was provided by Bouzid et al., who considered the tumor growth kinetics (TGK), defined as the difference in the sum of the largest diameters of target lesions (according to RECIST criteria) per unit of time. A TGK $R$ $\geq 2$ (= the ratio between TGK on therapy and TGK before therapy) was an indicator of HPD [30]. One of the main disadvantages of criteria based on radiological evaluations is that prebaseline computed tomography (CT) scans are not always available, especially in the case of first-line therapy. Therefore, other studies provided definitions of HPD also considering clinical parameters. For instance, in their classification of HPD, Kato et al. also considered time-to-treatment failure (TTF), defined as the time from the start of treatment to discontinuation for any reason. In their work, they described HPD as a condition

Table 1 HPD rates in different clinical studies

\begin{tabular}{llll}
\hline Type of cancer & $\mathbf{N}^{\circ}$ of patients & HPD rate (\%) & Reference \\
\hline Different types of cancer & 131 & 9 & {$[24]$} \\
NSCLC & 335 & 13.1 & {$[25]$} \\
Gastric cancer & 36 & 11.1 & {$[26]$} \\
Different types of cancer & 182 & 6.6 & {$[27]$} \\
NSCLC & 406 & 13.8 & {$[28]$} \\
NSCLC & 152 & 25.7 & {$[29]$} \\
HNSCC & 34 & 29 & {$[30]$} \\
Different types of cancer & 155 & 4 & {$[31]$} \\
\hline
\end{tabular}


with a TTF lower than 2 months, an increase of more than $50 \%$ in tumor burden compared to pretherapy imaging and a more than two-fold increase in progression pace [31]. Moreover, in the study by Lo Russo et al., patients were diagnosed with HPD when they showed at least three of these criteria: TTF less than 2 months, an increase of more than $50 \%$ of the sum of target lesion major diameters between baseline and first radiological evaluation, appearance of at least two new lesions in an organ already involved based on baseline and first radiological evaluation, spread of the disease to a new organ, and a decrease in Eastern Cooperative Oncology Group (ECOG) performance status more than 2 during the first 2 months of treatment [29]. Considering the existence of several alternative definitions of HPD, summarized by Frelaut et al. [32], it follows that the percentage of HPD patients can vary widely among the different studies (from 4 to $29 \%$ of ICI-treated patients). Overcoming these differences is necessary to facilitate the interpretation of data obtained from different clinical studies and to begin rigorous epidemiological analyses in this field and, not least, to identify possible predictive markers of HPD that, to date, are not available. The discovery of possible predictive markers follows two different paths: the study of the host or the tumor [32,33]. The former is focused on the patient's general characteristics, such as age, gender, previous exposure to other therapies, or on the host immune system, such as the presence of a specific tumor-infiltrating or circulating immune cell population. The latter is aimed at analyzing intrinsic tumor features, such as specific genetic alterations, chromosomal instability, and tumor mutational burden.

Second, to date, the molecular and cellular mechanisms underlying the occurrence of HPD are not known. Since 2017, many hypotheses and speculations have been made to provide a fully convincing explanation of this extremely negative effect associated with ICI therapy.

\section{Hyperprogressive disease: an unsolved problem}

In summary, HPD represents a serious problem in the era of immunotherapy for different reasons: (i) it involves a broad spectrum of cancers and is not restricted to a particular tumor histotype; (ii) there is no univocal definition of HPD; (iii) no reliable predictor markers have been identified yet; and (iv) the cellular and molecular mechanisms are still unclear despite several studies providing interesting suggestions and hypotheses. The aim of the present work is to provide an overview of the data available in the literature that might help to elucidate this clinical phenomenon. We also included some reports that, although not strictly related to HPD, allow us to understand that ICIs can trigger undesired effects.

\section{Possible immune-related mechanisms of HPD}

PD-1 is an inhibitory receptor expressed on adaptive and innate immune cells such as $\mathrm{T}$ lymphocytes, B lymphocytes, monocytes, macrophages, natural killer (NK) cells, and dendritic cells (DCs) [34]. Upon engagement with its ligands (PD-L1 and -L2), this receptor triggers a signaling pathway leading to the inhibition of immune cell function, which can be reverted using specific antibodies able to disrupt the PD-1/PD-L1 axis [35]. ICIs enhance endogenous antitumor immune responses in patients with a wide range of cancers [4]. If the final outcome of ICI-based therapy strictly relies on how immune cells respond to anti-PD-1/PD-L1 antibodies, it is plausible to speculate that HPD may be caused by an undesired response of the immune system to these antibodies. It is difficult to address this question since PD-1 blockade is usually associated with the restoration of the immune response. However, it is possible to find some data that suggest that blocking PD-1 does not always attain the desired effect.

\section{Undesired effects of PD-1 blockade on innate immunity} NK cells actively participate in immune attack against tumors, but their cytotoxic activity is often dampened by the expression of immune checkpoints such as PD-1 [36]. PD-1 blockade not only elicits strong $\mathrm{T}$ cells but also restores the NK cell antitumor response [37, 38]. However, using a mouse model of gram-negative infection, Solaymani-Mohammadi et al. observed that PD-1 knock-out (KO) mice or anti-PD-1 antibody-treated mice were more susceptible to bacterial infection than wild-type (WT) mice. This observation was explained by the fact that the lack of PD-1 impairs the expression of NK cell effector molecules such as granzyme B and perforin [39]. Therefore, this work suggests that, in certain contexts, intact PD-1 signaling in NK cells is required to maintain the full functionality of these immune cells.

ILC1, ILC2 and ILC3 represent the three main subsets of helper innate lymphoid cells (ILCs) that can be considered the innate counterparts of $\mathrm{CD}^{+} \mathrm{T}$ helper 1 $\left(\mathrm{T}_{\mathrm{H}} 1\right), 2\left(\mathrm{~T}_{\mathrm{H}} 2\right)$, and $17\left(\mathrm{~T}_{\mathrm{H}} 17\right)$ cells, respectively. ILCs contribute to the regulation of both the innate and adaptive immune systems through cytokine secretion after activation by different stimuli [40]. ILCs participate in the antitumor immune response or promote tumor development depending on the secreted cytokines and the tumor microenvironment in which they exert their immunomodulatory functions [41]. Analyzing two patients who received anti-PD-1 immunotherapy and developed HPD after treatment, Xiong et al. found that ILC3associated genes were enriched in tumors after anti-PD1 administration, suggesting that the ILC3 population may be involved in HPD development [42]. However, the mechanisms by which ILC3 cells may promote HPD 
are still unknown. ILC3 cells have been reported to express functional PD-1 $[43,44]$, which plays a negative regulatory role in cytokine production upon PD-L1 engagement [43]. It is possible that the disruption of the PD-1/PD-L1 axis mediated by anti-PD-1 antibody might determine a reactivation of these cells with a consequent release of cytokines that, as already mentioned, can have protumor activity in certain types of cancers [45, 46]. Moreover, ILC3 can dampen the $\mathrm{T}$ cell response by competing with T cells for IL-2 [47], further strengthening the immunosuppressive microenvironment.

Dendritic cells (DCs) are the most potent antigenpresenting cells (APCs) able to induce effective adaptive immune responses and, for this reason, represent a key factor in determining the success of ICI therapy [48]. Tumor-infiltrating dendritic cells (TIDCs) are a heterogeneous myeloid immune population characterized by different maturation statuses and functions: some subsets have immunostimulatory properties able to promote antitumor immunity, while other subsets are immunosuppressive and can favor tumor immune escape and progression $[49,50]$. As mentioned, PD-1 can also be expressed by DCs, and the presence in the tumor microenvironment of PD- $1^{+}$TIDCs has been observed [51]. PD-1 maintains DCs in an immature phenotype, suppressing cytokine production, costimulatory molecule expression and antigen presentation capacity [51, 52]. PD-1 expression can be regulated by different stimuli, such as IL-10 [53]. Interestingly, it was found that PD-1 blockade on PD- $1^{+}$DCs promotes an augmented release of IL-10 by these immune cells that, in turn, determines an upregulation of PD-1 on the DC cell membrane, creating a vicious loop eventually leading to enhanced immunosuppression [53]. Another intriguing function of PD-1 in DCs has been described by the work of Zhao et al. [54]. The authors demonstrated that PD-1 and its ligand PD-L1 are simultaneously coexpressed on a subset of tumor-infiltrating APCs that interact with each other on the same cell membrane. In this way, PD-1 on DCs sequesters PD-L1, neutralizing its ability to bind PD-1 expressed by T cells. After anti-PD-1 antibody administration, this binding is disrupted, and PD-L1 is again available to elicit immunosuppressive activity on $\mathrm{T}$ cells [54].

Monocytes are a population of innate immune cells that circulate in the bloodstream and move to tissues to reach the site of infection or inflammation. During cancer development, different monocyte subsets were found to have completely different functions contributing to both pro- and antitumor immunity. Moreover, monocytes are the primary source of tumor-associated macrophages (TAMs) and dendritic cells (DCs), two important components of the tumor microenvironment [55]. Although much less investigated than in $\mathrm{T}$ lymphocytes,
PD-1 can also be expressed by monocytes, and its upregulation can be mediated by different inflammatory stimuli [56-59], such as IL-10, already described as a PD-1 inducer in DCs [53, 60]. The role of PD-1 in monocytes appears to be very similar to that described for other immune cells, a substantial inhibition of immune function. Indeed, PD-1 was reported to negatively impact IL-12 production by monocytes [61, 62], and PD-1 blockade reverses monocyte dysfunction [63]. However, monocytes release large amounts of IL-10 upon PD-1 triggering by specific antibodies [56, 64].

Although these data do not represent a mechanistic explanation of HPD, they allow us to understand that PD-1 biology is far from completely elucidated, especially in non-T cells. What emerges from these works is that, in specific cases, anti-PD-1 antibodies can exacerbate the immunosuppressive capacity of the cells of the innate immune system. This occurs, for example, during viral or bacterial infections or, sometimes, in tumors, all clinical conditions characterized by the high concentration and circulation of immunomodulatory molecules, such as cytokines, pathogen- or damage-associated molecular patterns (PAMPs or DAMPs) [65-67]. Innate immune cells are extremely adaptable, as they have the ability to completely change their phenotype and behavior as a result of the combination of the received stimuli [68]. These profound modifications may also have an impact on the pathways governed by PD-1. Therefore, PD-1 blockade might result in diametrically opposite outcomes depending on the phenotype acquired by these cells. A summary of the proposed innate immunemediated mechanisms is provided in Table 2.

\section{Unexpected effects of PD-1 blockade on adaptive immunity}

Anti-PD-1 therapy was initially designed to restore $\mathrm{T}$ cell-based immune attack against tumors [35]. However, it is important to recall that PD-1 represents a master negative regulator of $\mathrm{T}$ lymphocyte function; therefore, its blockade might trigger compensatory mechanisms aimed at keeping $\mathrm{T}$ cell activity under control [69-71]. This negative regulatory feedback might overcome the benefit of anti-PD-1-based therapy in terms of $\mathrm{T}$ cell activation and might establish an enhanced immunosuppressive environment, creating the conditions for HPD development. For example, it has been reported that tumor-associated lymphocytes (TALs) or tumor-infiltrating lymphocytes (TILs), isolated from a mouse model of metastatic ovarian cancer or human ovarian cancer patients, simultaneously express several immune checkpoint inhibitory receptors, such as PD-1, LAG-3, and CTLA4 , that participate in creating an extremely immune- 
Table 2 Possible immune-mediated mechanisms of HPD involving innate immune cells

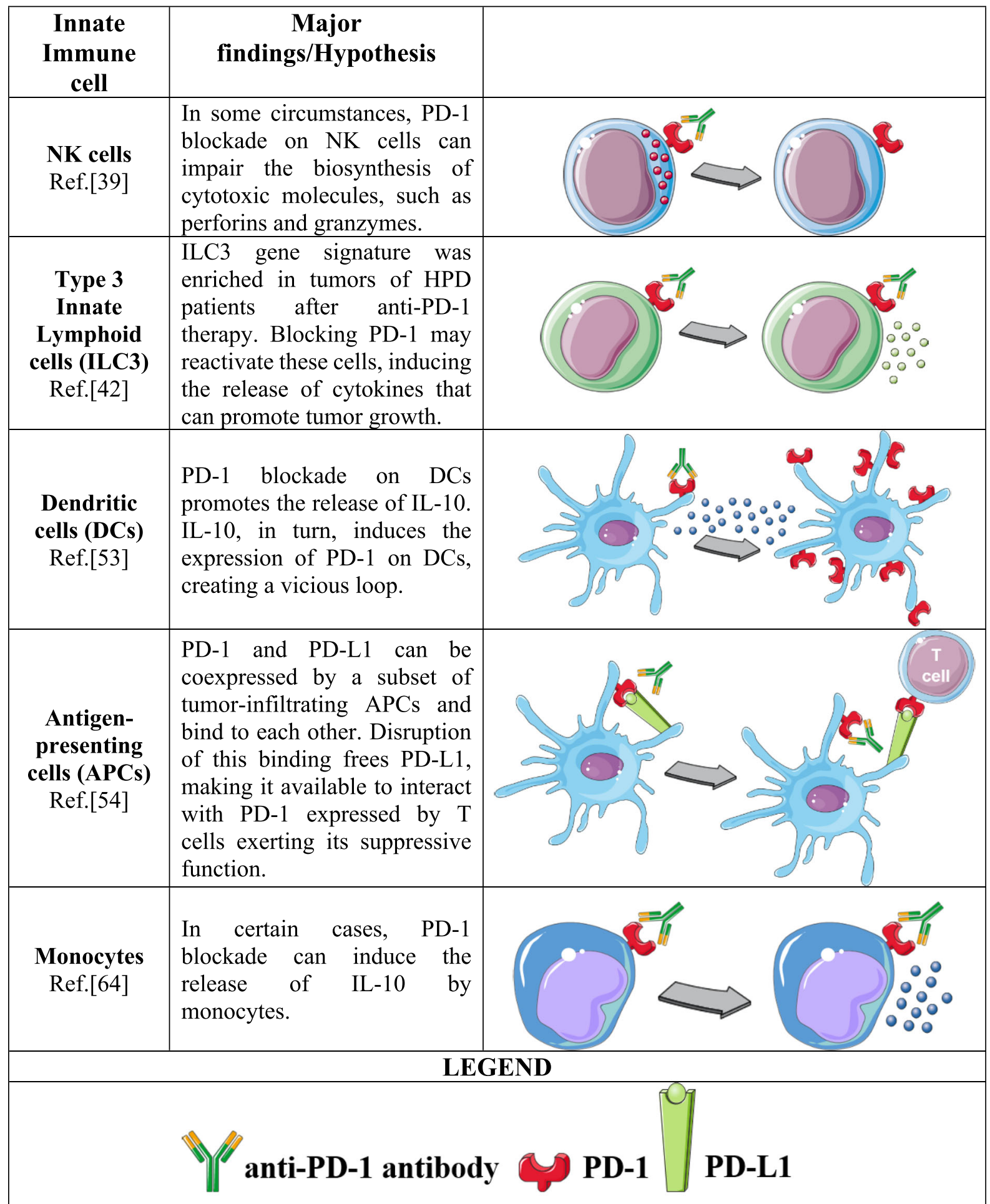

Possible role of the innate immune system in determining HPD. In certain contexts, blocking PD-1 on innate immune cells may induce or exacerbate the immunosuppressive activity of these cells

suppressed TME. Interestingly, the individual blockade of one of those receptors can lead to the up-regulation of the others, nullifying the benefit of ICI therapy [69]. On the same line, Koyama et al. observed, in mice and humans, an increased expression of the immune checkpoint T-cell immunoglobulin mucin-3 (TIM-3) on 
$\mathrm{T}$ cells after anti-PD-1 antibody administration [72]. However, these negative regulatory mechanisms are not only restricted to the immune checkpoints, but also involve other proteins that can contribute to the immune regulation. For instance, it was found that PD- $1^{\text {high }}$ melanoma antigen-specific $\mathrm{CD}^{+} \mathrm{T}$ cells express high levels of IL-10 receptor (IL-10R) that can be further increased by PD-1/ PD-L1 axis disruption, making these cells more sensitive to IL-10 [73]. If PD-1 blockade might induce IL-10 secretion by innate immune cells, as described in the previous section, and a parallel upregulation of IL-10R on $\mathrm{T}$ cells, these two combined events might cause severe dampening of $\mathrm{CD}^{+} \mathrm{T}$ cell antitumor activity, favoring tumor growth.

Moreover, the $\mathrm{T}$ lymphocyte family comprises not only effector cells but also an immunoregulatory subset, named regulatory $\mathrm{T}$ cells $\left(\mathrm{T}_{\text {regs }}\right)$, whose duty is to negatively control other immune cells and to prevent autoimmunity [74]. In tumors, the presence of $\mathrm{T}_{\text {regs }}$ represents an unfavorable factor for the host since they constrain an efficacious antitumor immune response [74]. $\mathrm{T}_{\text {regs }}$ can also express PD-1 [75], and therefore, they can be targeted by anti-PD-1 antibodies. Based on previously published data indicating that PD-1 and FoxP3 cooperate for the maintenance of fully functional $\mathrm{T}_{\text {regs }}$ [76], Kamada et al. explored how PD-1 blockade can influence $\mathrm{T}_{\text {reg }}$ behavior in the context of HPD [26]. By examining 14 paired (preand post-treatment) fresh tumor samples obtained from 2 HPD and 12 non-HPD gastric cancer patients, the authors found that after anti-PD-1 antibody treatment, the ratio between proliferating $\left(\mathrm{Ki} 67^{+}\right)$effector $\mathrm{T}_{\text {regs }}\left(\mathrm{eT}_{\text {regs }}\right)$ and $\mathrm{Ki} 7^{+} \mathrm{CD}^{+} \mathrm{T}$ cells among the tumor-infiltrating lymphocyte (TIL) compartment remained stable in HPD patients, while it was reduced in the non-HPD group. These data led to the hypothesis that if the frequency of $\mathrm{CD}^{+}$lymphocytes does not overcome the frequency of $\mathrm{eT}_{\text {regs }}$, there is an increased possibility of developing HPD. A deeper analysis, conducted to better define $\mathrm{eT}_{\text {reg }}$ phenotype, revealed that $\mathrm{PD}-1^{+} \mathrm{eT}_{\text {regs }}$ proliferated more than their $\mathrm{PD}-1^{-}$counterparts and that $\mathrm{PD}-1^{+} \mathrm{eT}_{\text {reg }}$ proliferation can be further increased by anti-PD-1 antibody treatment. In summary, blocking PD-1 on PD$1^{+} \mathrm{eT}_{\text {regs }}$ enhanced their immunosuppressive ability. The observations made in the human setting were confirmed using a mouse model in which $\mathrm{T}_{\text {regs }}$ were made deficient in PD-1 expression. Knocking out PD-1 in $\mathrm{T}_{\text {regs }}$ resulted in greater proliferation paralleled by a more potent immunosuppressive capacity of these immune cells, resulting in the ability to boost tumor growth when transplanted into tumor-bearing mice [26].

Based on the previously described data, when we consider the possible mechanisms involving adaptive immune cells, it is reasonable to indicate $T_{\text {regs }}$ as the prime suspects in the context of HPD. However, it should be taken into consideration that also non- $\mathrm{T}_{\text {regs }}$ $\mathrm{CD} 4^{+}$cells are not above suspicion.

It is certainly true that the role of non- $\mathrm{T}_{\text {regs }} \mathrm{CD} 4^{+}$lymphocytes during ICI therapy has not been deeply investigated as for $\mathrm{CD}^{+}$cells, even if they exert fundamental functions, for instance initiating and sustaining the immune response, as recently reviewed in [77]. Therefore, as already described for other immune cells, it is likely to expect that, in particular circumstances, also non$\mathrm{T}_{\text {regs }}$ lymphocytes can unexpectedly respond to ICI therapy, resulting in a detrimental outcome. Indeed, to this regards, it is possible to find some insights in the literature. For example, analyzing a cohort of 70 lung cancer patients treated with anti-PD-1 or anti-PD-L1 antibodies after progression to platinum-based chemotherapy, Arasanz and co-coworkers performed an immunophenotyping on peripheral blood samples collected at baseline and after the second cycle of treatment, focusing their attention on $\mathrm{CD}^{+}$lymphocytes. The obtained results were then correlated to patient clinical outcome. They found that HPD patients were characterized by a strong expansion of highly differentiated $\mathrm{CD} 28^{-} \mathrm{CD} 4^{+} \mathrm{T}$ cells, defined as $\mathrm{CD} 4^{+} \mathrm{T}_{\mathrm{HD}}$, between the first and second cycle of therapy. Accordingly, the evaluation of tumor growth kinetics, higher in the HPD group, correlated with a greater presence of this $\mathrm{CD} 4^{+}$subpopulation. Although more detailed analyses are required to better characterize the phenotype of $\mathrm{CD}^{+} \mathrm{T}_{\mathrm{HD}}$ lymphocytes, this work highlights the fact that also non- $\mathrm{T}_{\text {regs }} \mathrm{CD} 4^{+}$ cells may play an active role in triggering HPD [78].

Another important evidence about the possible involvement of non- $\mathrm{T}_{\text {regs }} \mathrm{CD} 4^{+}$lymphocytes in determining HPD comes from the work by Zappasodi et al. The Authors observed, in a mouse model of melanoma, that a subpopulation of $\mathrm{CD} 4^{+}$Foxp $3^{-} \mathrm{PD}-1^{\text {high }}$, named $4 \mathrm{PD}-$ $1^{\text {hi }}$, is present in the TME and that its frequency is correlated with the tumor size. Subsequent analyses revealed that $4 \mathrm{PD}-1^{\text {hi }}$ cells can exert immunosuppressive function by limiting proliferation, activation and proinflammatory cytokine production of $\mathrm{CD}_{4}^{+}$and $\mathrm{CD} 8^{+} \mathrm{T}$ cells, both in humans and mice. Although characterized by immunosuppressive properties, 4PD- $1^{\text {hi }} \mathrm{T}$ lymphocytes are distinct from $\mathrm{T}_{\text {regs }}$, since RNA-based sequencing expression profile and phenotypic analysis showed that they are more similar to $\mathrm{CD} 4^{+}$follicular helper $\mathrm{T}$ $\left(\mathrm{T}_{\mathrm{FH}}\right)$ cells. For the purpose of the present Review, the most intriguing data is that, while anti-PD-1 antibody treatment was able to reduce the number of these lymphocytes, anti-CTLA4 antibody administration increased their intra-tumor abundance, most probably due to an excessive $\mathrm{T}$ cell priming mediated by $\mathrm{B}$ lymphocytes [79]. Therefore, these data provide the demonstration 
Table 3 Possible immune-mediated mechanisms of HPD involving T cells

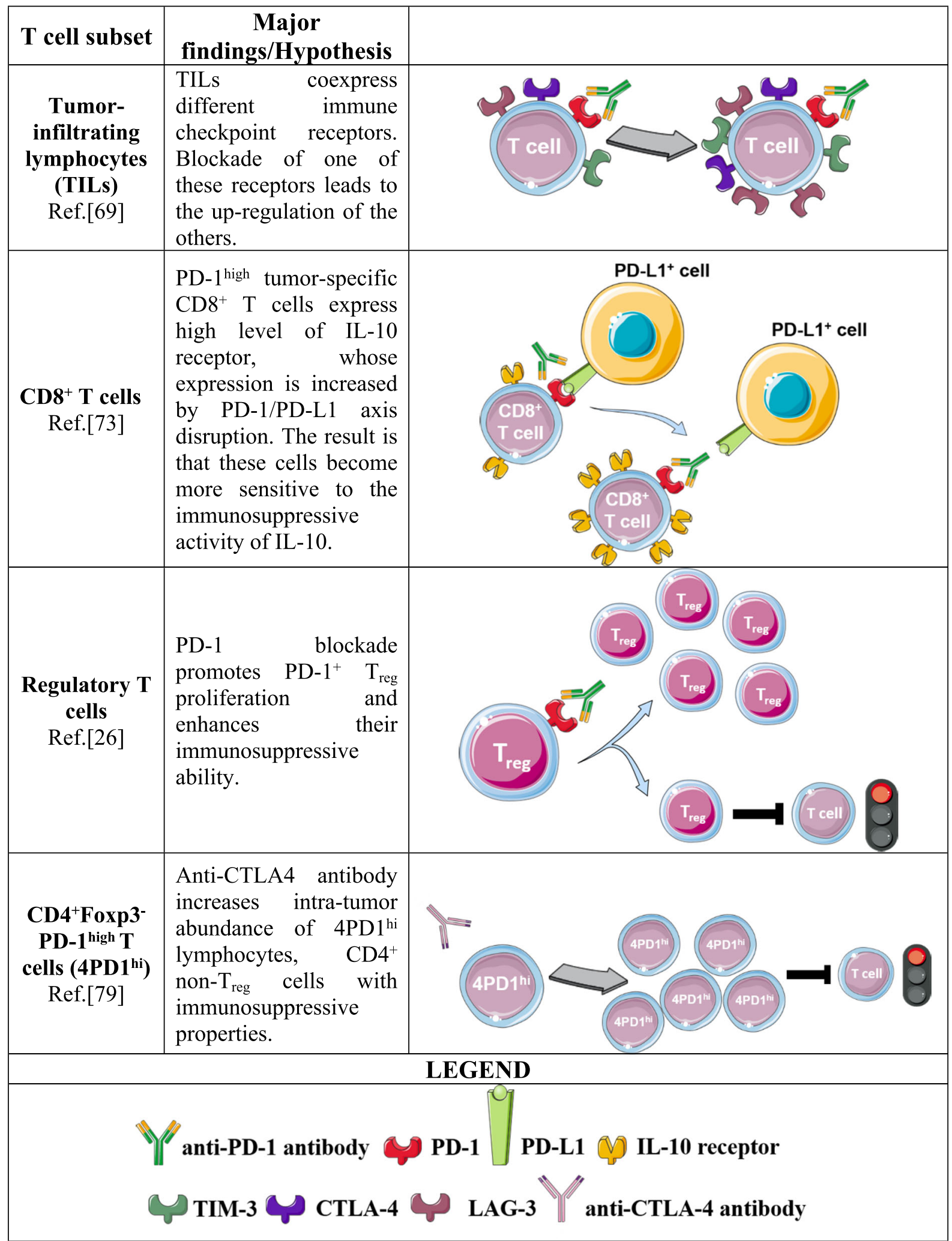

Possible role of T lymphocytes in determining HPD. PD-1 blockade increases the expression of other immune checkpoint receptors on tumor-infiltrating lymphocytes or determines the upregulation of L-10 receptor on CD8 ${ }^{+} \mathrm{T}$ cells, making these cells more sensitive to IL-10-mediated immune suppression. Moreover, blocking PD-1 on $\mathrm{T}_{\text {regs }}$ exacerbates their immunosuppressive properties, while anti-CTLA4 antibody promotes the proliferation of CD4+Foxp3-PD-1 $1^{\text {high }} \mathrm{T}$ cells, lymphocytes with immunosuppressive properties 
that also non- $\mathrm{T}_{\text {regs }} \mathrm{CD} 4^{+}$lymphocytes can unexpectedly respond to ICI therapy, in this specific case to CTLA-4 blockade, not only increasing their proliferation but also acquiring negative regulatory immune properties. Although the Authors considered these cells only a negative prognostic factor of ICI, it is undeniable that an augmented presence of these immunosuppressive cells may represent a fertile ground for HPD development.

While the role played by $\mathrm{T}$ lymphocytes and, in particular, by $\mathrm{T}_{\text {regs }}$ in the context of HPD is now well delineated, when considering B lymphocytes, it appears that $B$ cells may not be involved in inducing the detrimental effect associated with ICI therapy. B cells can express PD-1, and it is now recognized that anti-PD-1 antibodies can enhance humoral immunity [80]; accordingly, some authors found the presence of B lymphocytes in the TME to be positively correlated with a favorable outcome to PD-1 blockade therapy [81, 82]. On the other hand, other researchers found that the absence of B cells does not have any impact on the efficacy of immunotherapy [83]. These discrepancies might be explained by the fact that there are many subsets of B cells, each of them with its peculiar functions [84-86]. Therefore, depending on the presence in the tumor bed of a particular $B$ cell population, the final ICI therapy outcome can vary greatly. Although B lymphocytes can influence ICI therapy outcome, based on the available data, there is no evidence that these immune cells participate in determining HPD. A summary of the proposed adaptiveimmune-mediated mechanisms is provided in Table 3.

\section{Role of the fc domain}

The publications reported so far describe the effects of the binding between ICIs and their own specific antigens (i.e., PD-1 or PD-L1). However, an antibody is composed of two functionally distinct domains: the $\left.\mathrm{F}(\mathrm{ab})_{2}\right)_{2}$ fragment that binds the antigen and the fragment crystallizable $(\mathrm{Fc})$ region that is recognized by membrane molecules expressed by several immune cells, named immunoglobulin Fc receptors (FcRs) [87, 88]. The interaction between the Fc domain of an antibody and its cognate FcR triggers a cascade of immune events stimulating phagocytic or cytotoxic cells to eradicate pathogens or infected/tumor cells through different mechanisms, such as antibody-dependent cell-mediated cytotoxicity (ADCC), complement-dependent cytotoxicity (CDC) and antibody-mediated phagocytosis (ADCP) $[87,89]$. To avoid the killing of $\mathrm{T}$ cells that express ICs, most ICIs were developed by choosing antibody isotypes with low or significantly reduced binding to FcRs [90-92]. Indeed, nivolumab and pembrolizumab, anti-PD-1 antibodies, are IgG4, an isotype considered immunologically inert but that still retains the ability to bind Fc $\gamma$ RI and FcyRIIb, activating and inhibitory FcRs, respectively [90-92]. In this regard, it has been reported that tumor-associated macrophages (TAMs) are able to capture anti-PD-1 antibodies from the $\mathrm{T}$ cell membrane through FcyRIIb [93].

Although it is not known whether this interaction may have biological consequences, our work provided some important insights [29]. Analyzing NSCLC tumor specimens collected before the initiation of ICI immunotherapy, we observed the presence of peculiar clusters of TAMs characterized by epithelioid morphology and CD163, CD33 and PD-L1 coexpression in all HPD patients, suggesting the involvement of macrophages in HPD occurrence. To investigate whether these innate immune cells could play a role in inducing HPD, in vivo experiments using different NSCLC immunodeficient mouse models were performed. We were able to reproduce HPD-like progression in mice after anti-PD-1 antibody administration. Subsequent analyses suggested that, as in cancer patients, a particular macrophage population present in the TME before starting anti-PD-1 antibody therapy might be the immune cell responsible for the development of HPD through a mechanism that does not involve the direct blocking of PD-1 on these immune cells. Therefore, we speculated that the detrimental boost in tumor growth may be ascribed to the Fc domain of the antibody. Indeed, the use of the anti-PD-1 antibody $\mathrm{F}(\mathrm{ab})_{2}$ fragment as well as macrophage depletion completely abrogated the marked increase in tumor growth observed with the whole antibody. Since antiPD-1 antibody is able to bind the inhibitory receptor FcyRIIb, we imagined a scenario in which a particular subset of TAMs expressing the inhibitory receptor Fc $\gamma$ RIIb undergoes functional reprogramming after interaction with the Fc domain of the anti-PD-1 antibody acquiring enhanced pro-tumor properties, eventually inducing HPD [29].

Another explanation regarding the possible role Fc $\gamma$ RIIb in the context of HPD came from the comment made by Knorr and Ravetch to [29]. Based on prior studies describing that the in vivo activity of some therapeutic antibodies is dependent on FcyRIIb expression in the TME, the Authors described a situation in which anti-PD-1 antibody creates a type of bridge between $\mathrm{Fc}_{\mathrm{RIIb}}{ }^{+}$immune cells and $\mathrm{PD}-1^{+}$macrophages. This interaction may be able to induce the clustering of several PD-1 molecules on macrophage membranes. The close proximity of different PD-1 proteins may trigger PD-1-mediated signaling, leading to macrophage polarization towards the pro-tumor phenotype [94].

Although FcyRIIb is potentially responsible for HPD through at least two distinct mechanisms, the involvement of other FcRs cannot be excluded. For instance, Swisher et al. showed that IgG4 immune complexes (ICs) were able to limit the response to IFN- $\gamma$ in human 
Table 4 Possible mechanisms of HPD involving the interaction between the ICI Fc domain and macrophage Fc receptors

\begin{tabular}{|c|c|c|}
\hline $\begin{array}{c}\text { Cells } \\
\text { involved }\end{array}$ & Hypothesis & \\
\hline $\begin{array}{c}\text { PD-1 }{ }^{+} \text {cells } \\
\text { (immune or } \\
\text { tumor cells) } \\
\text { and } \\
\text { macrophages } \\
\text { Ref.[29] }\end{array}$ & $\begin{array}{l}\text { Upon binding to PD-1 on } \\
\text { PD- } 1^{+} \text {cells, the anti-PD-1 } \\
\text { antibody Fc domain } \\
\text { interacts with an Fc receptor } \\
\text { (FcyrIIb?) expressed by } \\
\text { macrophages. } \\
\text { interaction This } \\
\text { functional reprogramming } \\
\text { of macrophages towards a } \\
\text { stronger promotes } \\
\text { phenotype. }\end{array}$ & macrophage \\
\hline $\begin{array}{c}\text { FcyRIIb }{ }^{+} \text {cells } \\
\text { (i.e., myeloid } \\
\text { cells) and } \\
\text { macrophages } \\
\text { Ref.[94] }\end{array}$ & $\begin{array}{l}\text { FcyrIIb, expressed by } \\
\text { myeloid cells, promotes the } \\
\text { clustering of PD-1 } \\
\text { molecules on the membrane } \\
\text { of macrophages. The close } \\
\text { proximity of several PD-1 } \\
\text { proteins causes the } \\
\text { triggering of PD-1 signaling } \\
\text { with a consequent } \\
\text { polarization of macrophages } \\
\text { towards a pro-tumor } \\
\text { phenotype. }\end{array}$ & Fc $\gamma R$ IIIb+ cell \\
\hline \multicolumn{3}{|c|}{ LEGEND } \\
\hline
\end{tabular}

The engagement of an unidentified Fc receptor expressed by TAMs by the anti-PD-1 antibody Fc domain may directly trigger a functional reprogramming of these immune cells or may induce the clustering of PD-1 on macrophages, leading, in both cases, to the acquisition of an enhanced pro-tumor phenotype

monocyte-derived macrophages through the FcyRI interaction. Moreover, the activation of FcyRI mediated by IgG4 ICs polarized monocyte-derived macrophages towards the M2-like phenotype [95]. The Fc-mediated mechanisms of HPD are summarized in Table 4.

\section{Possible tumor-related mechanisms of HPD}

Considering that HPD consists of a rapid increase in tumor growth after ICI administration, this marked acceleration of the disease may not be a mere reflection of an unexpected response of the immune system to ICI treatment, but it is possible that intrinsic characteristics of tumor cells may play an active role in determining this clinical phenomenon. Indeed, many efforts have focused on understanding whether particular tumor genomic alterations are responsible for HPD occurrence to find a biomarker suitable to predict HPD. However, the majority of the published studies only describe an association between the tumor mutational landscape and HPD, and very rarely, a possible mechanistic explanation has been provided.

\section{MDM2/MDM4 amplification and EGFR alteration}

The first genomic alterations that were associated with HPD are MDM2/MDM4 amplification and EGFR mutation [31]. The biological function of $M D M 2$ (murine double minute 2) and its homolog MDM4 is to negatively regulate the tumor suppressor p53 by promoting its proteasome degradation [96]. By analyzing 155 stage IV patients affected by different types of cancers using next-generation sequencing (NGS), Kato et al. observed that in a cohort of 155 patients with advanced cancers, 
49 (31.6\%) had a TTF $<2$ months; 6 of them had $M D M 2 / M D M 4$ amplifications that were found to be an independent predictor of poor clinical outcome by multivariate analysis. Among these 6 patients, 4 were identified as hyperprogressors. Subsequently, this finding was also supported by several other studies [97-99]. Although the mechanism by which $M D M 2 / M D M 4$ amplifications could induce HPD is unknown, the Authors hypothesized that the increase in IFN- $\gamma$ levels in the TME following ICI administration [100] may trigger JAK/STAT signaling [101] in tumor cells, resulting in an upregulation of the interferon regulatory factor $(I R F)-8$ gene [102]. IRF8 is known to bind the MDM2 promoter, favoring its expression [103]. Therefore, an augmented MDM2 level may determine a stronger p53 inhibition leading to a dysregulation of cancer cell proliferation. However, the relevance of MDM2 in affecting ICI therapy outcome has been highlighted by the work of Fang et al. To investigate how p53 can influence the response to anti-PD-1 immunotherapy, the authors evaluated the ability of the MDM2 inhibitor APG-115, currently under clinical investigation (ClinicalTrials.gov Identifier: NCT02935907), to improve the effect of anti-PD-1 treatment. In vitro and in vivo studies have shown that APG115 can modulate the immune response by repolarizing protumor M2 macrophages towards an M1 phenotype, enhancing $\mathrm{T}$ cell activation and upregulating PD-L1 expression on tumor cells. Finally, APG-115 was able to enhance PD-1 blockade antitumor activity [104]. Since it has been reported that MDM2 can modulate anti-PD-1 antibody efficacy, its involvement in HPD onset cannot be excluded.

In addition to $M D M 2 / M D M 4$ amplifications, the analysis provided by Kato et al. revealed that 2 out of 10 patients with EGFR alterations experienced HPD. Accordingly, other studies reported similar observations. EGFR was the first member of the ErbB family to be discovered, and it plays a significant role in many cellular processes essential for survival and cell growth. EGFR is also known to be involved in the pathogenesis and progression of different types of cancers [105] and in promoting immune escape through different mechanisms, such as the upregulation of PD-L1, the downregulation of tumor antigen presentation, and the induction of secretion of metabolites and molecules with immunosuppressive properties in the TME [106]. Therefore, mutations in this receptor may be associated with nonresponse to ICI therapy $[107,108]$, but the possible link between EGFR and HPD remains unknown.

\section{PD-L1 and VEGFR2 polymorphisms}

Other possible HPD-related genomic alterations were identified by Refae and coworkers [109]. The Authors evaluated the frequency of 17 SNPs in 4 genes ( $P D-1$,
$P D-L 1, I D O 1$ and VEGFR2), selected for their functional and clinical relevance, in a cohort of 98 patients, affected by different types of cancer and treated with anti-PD-1 or anti-PD-L1 monotherapy alone. In this cohort, $14 \%$ of patients experienced HPD during therapy. Multivariate analysis revealed that the polymorphisms rs2282055 G allele in the $P D-L 1$ gene and rs1870377 A allele in the VEGFR2 gene are significantly and independently associated with a higher susceptibility to developing HPD. Based on the data available in the GTEX portal, the Authors hypothesized that rs2282055 PD-L1 polymorphisms may have a role in regulating the PD-L1 expression level that, in turn, may impact ICI therapy outcome, even though the real influence of PD-L1 expression on ICI treatment is still a matter of debate [110]. In the case of the VEGFR2 gene, which encodes a receptor that responds to the VEGF signal and regulates endothelial migration and proliferation [111], rs1870377 is reported to increase the affinity and activity of VEGFA on VEGFR2 with the result of promoting angiogenesis, as reported in nonsmall cell lung cancer tissues [112]. Moreover, VEGFR2 can boost cancer proliferation and metastasis independently of proangiogenic stimuli [113]. Although these data are intriguing, they do not provide a biological explanation about how these polymorphisms and anti-PD-1/PD-L1 antibodies can work together in determining HPD. However, we can speculate that if ICIs are able to induce a stronger M2 phenotype in TAMs in some particular circumstances, as described in the previous section, one of the features of M2 macrophages is the ability to release VEGF that may more efficiently trigger the signaling pathways mediated by VEGFR2, exploiting the increased affinity of this receptor determined by the rs 1870377 polymorphisms. Of note, this work highlighted the possible existence of a tight link between angiogenesis and HPD, and in this regard, it is worth mentioning the ability of ICI to induce the expression of pro-angiogenic molecules. For example, Wu et al. reported an increased serum level of angiopoietin-2 (ANGPT2), a molecule involved in blood vessel maturation with potential protumor activity [114], in patients with advanced melanoma who progressed after ICI treatment [115]. The biological activity of ANGPT2 is not only restricted to neoangiogenesis but can also impact the macrophage phenotype by promoting PD-L1 expression [115] and IL-10 secretion [116], which, in turn, are involved in the expansion of $\mathrm{CD} 4{ }^{+} \mathrm{CD} 25^{\text {high }} \mathrm{Foxp}^{+}$Tregs in tumor-bearing mice [116]. These data suggest that ICI-induced angiogenesis might occur to create a stronger immunosuppressive microenvironment. Moreover, the augmented tumor growth kinetics presume higher energy consumption by tumor cells, and new vasculature formation may provide the nutrients required to sustain such rapid cell 
proliferation. Furthermore, HPD is often characterized by the appearance of metastatic foci, and more blood vessels vascularizing the tumor bed may represent an escape route for cancer cells, increasing the possibility for dissemination throughout the body.

\section{Alterations of KRAS, FBXW7 and STK11}

Sasaki et al. performed a retrospective study on 64 advanced gastric cancer (AGC) patients treated with nivolumab [117]. Among 13 patients who developed HPD after treatment, three showed $F B X W 7$ mutation, a tumor suppressor gene encoding a protein belonging to the proteasome systems [118], and three others showed amplification in the KRAS gene, a GTPase that regulates several cellular signaling pathways [119]. They also observed that absolute neutrophil count (ANC) and Creactive protein (CRP) level significantly increased only in patients with HPD during the first months of nivolumab treatment. Although the Authors speculated that higher ANC and CRP levels in HPD patients may be correlated with a strong release of neutrophils from bone marrow and a consequent accumulation of myeloid-derived suppressor cells (MDSCs) in tumors, the link with the reported genomic abnormalities was not explored.

Genomic alterations of the KRAS gene were also found in HPD patients by Kim et al. in a retrospective study of 335 patients with advanced NSCLC treated with antiPD-1 or anti-PD-L1 [25]. They found that 3 out of 16 patients with HPD had RAS/RAF mutations (two KRAS and one $R A F$ mutation) and, at the same time, serine/ threonine kinase 11 gene (STK11) truncating mutations, another tumor suppressor gene with a broad spectrum of functions ranging from cellular metabolism to regulation of apoptosis [120]. Based on a previously published work [72], the Authors speculated that the concomitant loss of STK11 together with mutations in an oncogenic pathway $(K R A S / R A F)$ promotes IL-6 secretion by tumor cells, which, in turn, can determine the recruitment of neutrophils in the tumor microenvironment.

Since a consistent infiltration of neutrophils can be associated with worse outcome to ICIs [121], one of the simplest method to evaluate their presence is the socalled neutrophil to lymphocyte ratio (NLR). NLR is calculated by dividing the number of neutrophils by the number of lymphocytes. These numbers are usually obtained from peripheral blood sample analysis, NLR represents a useful parameter utilized to evaluate the general immune response and systemic inflammatory status [122-124]. In the context of ICI, NLR demonstrated a very good clinical utility. For example, Mezquita et al. analyzed the neutrophils/(leukocytes neutrophils) ratio (dNLR), in a cohort of NSCLC patients treated with ICIs or standard chemotherapy.
The found that high dNLR (high number of circulating neutrophils) was independently associated with poor outcome in the ICIs but not in the chemotherapy group [125]. Similar results were also obtained in metastatic urothelial cancer where, again, NLR was significantly predictive of patients with progressive disease following ICIs [126]. Moreover, in a recently published conference proceeding, Ferrara et al. described a correlation between tumor and circulating neutrophils and HPD. The Authors reported the at the baseline, before the initiation of ICI treatment, the percentage of circulating immature low-density neutrophils, identified as $\mathrm{CD} 10^{-}$ $\mathrm{CD}_{15}{ }^{+} \mathrm{CD}_{66} \mathrm{~b}^{+}$cells, was significantly higher in HPD versus non-HPD patients. In addition, a subpopulation of $\mathrm{Gr} 1^{\text {high }} \mathrm{Ly} 6 \mathrm{C}^{\text {low }} \mathrm{IL}-17^{+}$neutrophils was found in mice treated with anti-PD-1 antibody that experience a HPDlike increase in tumor growth [127].

These results suggest that neutrophils can be considered as another important factor able to promote HPD, since an increased number of neutrophils at the tumor site may affect $\mathrm{T}$ cell number and function, exacerbating their exhaustion, resulting in a strong impairment of ICI activity.

\section{Tumor cell-intrinsic PD-1 expression}

PD-1 is expressed by adaptive and innate immune cells. However, it is emerging that this protein can also be present on a small fraction of tumor cells, but its exact function remains poorly understood. The main question about PD-1 expression on tumor cells is to determine whether this molecule can act as a tumor suppressor or can exert protumor activity.

Using the PD-1-expressing mouse lung cancer cell line $\mathrm{M} 109, \mathrm{Du}$ et al. found that PD-1 overexpression or treatment with recombinant PD-L1 decreased cell viability. Conversely, in vitro PD-1 blockade or silencing had the opposite effect. Moreover, in vivo PD-1 blockade accelerated M109 tumor growth [128]. Based on the obtained data, a model in which PD-1 function is similar to that described for $\mathrm{T}$ lymphocytes was proposed. The engagement of PD-1 by its cognate ligand PD-L1 triggers an inhibitory signaling cascade able to negatively impact tumor proliferation. When the PD-1/PD-L1 axis is disrupted by antibody treatment, these inhibitory signals are abolished, and cell proliferation can be reactivated. Notably, both the M109 cell line and tumor tissue from NSCLC patients express both PD-1 and PD-L1; therefore, the PD-1/PD-L1 interaction may occur in cis in the same tumor cells. The authors speculated that HPD may be the sum of several independent events. For example, if the tumor is highly infiltrated by PD- $1^{+} \mathrm{T}$ lymphocytes, whose activity is dampened by the presence of PD-L1 on tumor and immunosuppressive cells, PD-1 blockade can restore $\mathrm{T}$ cell-based antitumor 
Table 5 Possible tumor-mediated mechanisms of HPD

\begin{tabular}{|c|c|c|}
\hline $\begin{array}{c}\text { Cancer cell } \\
\text { characteristics }\end{array}$ & $\begin{array}{c}\text { Major } \\
\text { findings/Hypothesis }\end{array}$ & \\
\hline $\begin{array}{c}\text { MDM2/MDM4 } \\
\text { amplification } \\
\text { Ref.[31; 100- } \\
103]\end{array}$ & $\begin{array}{l}\text { The high IFN- } \gamma \text { level after } \\
\text { ICI administration can cause } \\
\text { an upregulation of IRF8 in } \\
\text { cancer cells. IRF8 binds } \\
\text { MDM2/MDM4 promoter } \\
\text { increasing their expression. } \\
\text { The augmented } \\
\text { MDM2/MDM4 level can } \\
\text { exert a strong inhibitory } \\
\text { activity on p53, stimulating } \\
\text { tumor cell proliferation. }\end{array}$ & $\begin{array}{l}\text { imor } \\
\text { cell }\end{array}$ \\
\hline $\begin{array}{c}\text { EGFR } \\
\text { alteration }\end{array}$ & Mechanism unknown & \\
\hline $\begin{array}{c}\text { VEGFR2 } \\
\text { polymorphisms } \\
\text { Ref.[109;112- } \\
113]\end{array}$ & $\begin{array}{l}\text { Polymorphisms in the } \\
\text { VEGFR2 gene can make } \\
\text { cancer cells more sensitive } \\
\text { to pro-angiogenic stimuli } \\
\text { but the exact mechanism } \\
\text { remains unknown. VEGFR2 } \\
\text { can also promote increased } \\
\text { cellular proliferation and } \\
\text { metastasis independently of } \\
\text { pro-angiogenic stimuli. }\end{array}$ & $\begin{array}{l}\text { creased } \\
\text { jiogenesis }\end{array}$ \\
\hline $\begin{array}{l}\text { KRAS and } \\
\text { STK11 } \\
\text { alterations } \\
\text { Ref. }[25 ; 72]\end{array}$ & $\begin{array}{l}\text { Recruitment of neutrophils } \\
\text { in the tumor } \\
\text { microenvironment mediated } \\
\text { by tumor IL-6 production } \\
\text { due to loss of STK11 and } \\
\text { simultaneous KRAS/RAF } \\
\text { mutation. The increased } \\
\text { number of neutrophils can } \\
\text { affect T cell infiltration and } \\
\text { function. }\end{array}$ & $\begin{array}{l}2.3 \\
2.3 \\
\text { eutrophil } \\
\text { ecruitment } \\
8\end{array}$ \\
\hline $\begin{array}{l}\text { Tumor cell- } \\
\text { intrinsic PD-1 } \\
\text { expression } \\
\text { Ref.[128-129] }\end{array}$ & $\begin{array}{l}\text { Blocking PD-1 expressed by } \\
\text { a subpopulation of cancer } \\
\text { cells can increase tumor } \\
\text { growth by activation of } \\
\text { AKT/ERK signaling } \\
\text { pathway. }\end{array}$ & \\
\hline \multicolumn{3}{|c|}{ LEGEND } \\
\hline
\end{tabular}

Peculiar genomic abnormalities in cancer cells as key determinants in triggering HPD upon ICl administration 

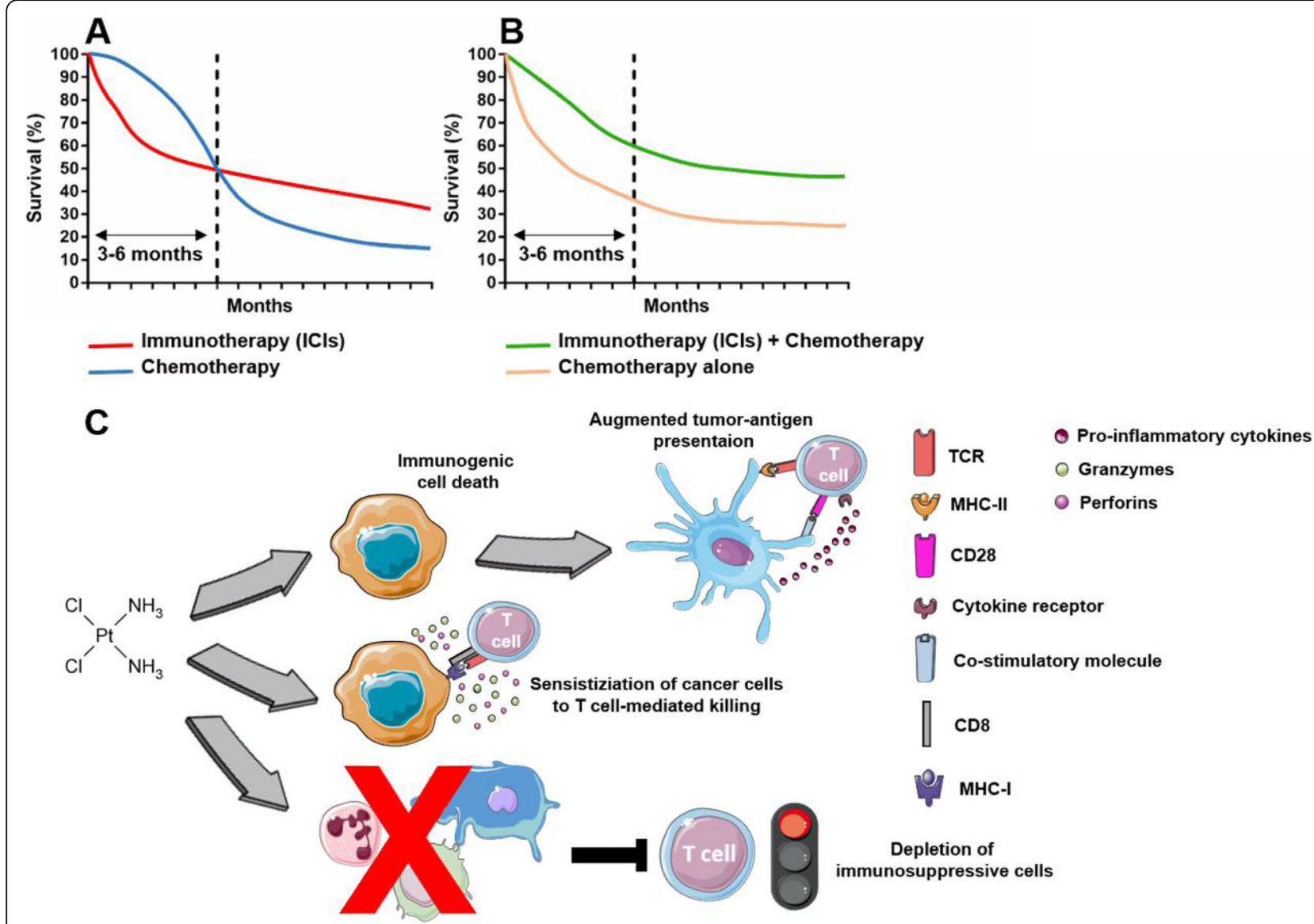

Fig. 1 Effect of chemotherapy on HPD. a Representative image of the crossover of the survival curves observed in clinical trials comparing ICls versus chemotherapy. $\mathbf{b}$ Representative image of survival curves observed in clinical trials comparing chemotherapy+lCls versus chemotherapy alone. c Overview of the main immunological effect of platinum compounds

immunity. On the other hand, in a poorly infiltrating tumor, the majority of the available PD-1 molecules are those expressed by tumor cells that, if bound by a specific antibody, can promote tumor growth. Similar results were also obtained by Wang et al., who demonstrated that PD-1 inhibitory activity in tumor cells relies on AKT and ERK1/2 signaling pathways [129]. However, other studies, performed using melanoma and hepatocellular carcinoma models, described a completely different situation in which blocking PD-1 directly on cancer cells determined a marked reduction in tumor proliferation [130, 131]. Collectively, these data suggest that tumor cell-intrinsic PD-1 can oversee different biological processes depending on the tumor type, and therefore, its inhibition can lead to opposite outcomes.

Moreover, it is possible to extend the role of PD-1 in tumor cells based on the findings described in [29]. Using NSCLC patient-derived xenografts (PDXs) treated with the anti-human PD-1 antibody nivolumab, the authors were able to exclude the involvement of mouse PD-1, since nivolumab only binds human PD-1 and not its mouse homolog. Therefore, in PDX models, the only source of human PD-1 is represented by tumor cells. As described before, an increase in tumor growth after nivolumab treatment was observed in some PDXs, a phenomenon that was completely abolished using nivolumab $\mathrm{F}(\mathrm{ab})_{2}$ fragments or macrophage depletion. The Authors speculated that binding of anti-PD-1 antibody on tumor cells allows the Fc domain of the antibody to be in the right conformation to be recognized by FcRs expressed by macrophages. The possible consequences of this interaction have been discussed in the previous section. A summary of the proposed tumor-mediated mechanisms is provided in Table 5 .

\section{Chemotherapy: an old solution to a new problem?}

The survival analysis of four important phase III clinical trials, conducted to evaluate the efficacy of ICI therapy in comparison to standard chemotherapy (CheckMate 057, CheckMate 141, Keynote 0456, IMvigor2117) [5, $12,132,133]$, revealed an increased rate of progression and deaths in the immunotherapy arm compared to 
chemotherapy arm in the first three-six months after the initiation of the therapy, as clearly showed by the crossover of the survival curves (Fig. 1a). This was the starting point that induced clinicians and scientists to interrogate about a possible negative effect associated with ICI therapy. Subsequent investigations led to the identification of a novel pattern of progression that was defined hyperprogression.

Although ICI demonstrated good clinical activity, data from human studies indicated that only a fraction of patients could really benefit of this type of therapy, that, unfortunately, in the majority of cases resulted largely ineffective or, as described above, even detrimental [134]. The current view is that tumors that are characterized by an inflamed/immunogenic phenotype, the socalled "hot" tumors, have the highest chance to properly respond to ICI. On the contrary, cancers that lack infiltration of effector cells, named "cold" tumors, can rarely be responsive to ICI. In order to revert these tumors from immune-deprived to inflamed, combination strategies with other immunotherapeutic drugs or chemotherapy, have been evaluated [135].

One of the pioneering study in this field was the Keynote 021 (NCT02039674), a randomized, open-label, phase II clinical trial conducted on chemotherapy-naive, stage IIIB or IV, non-squamous NSCLC without targetable EGFR or ALK genetic alterations. Patients received carboplatium plus premetrexed in combination or not with the anti-PD-1 antibody pembrolizumab. The obtained results demonstrated that the addition of ICIs to the chemotherapeutic regimen was well tolerated and that progression-free survival was significantly longer in the pembrolizumab plus chemotherapy group compared to chemotherapy arm. When considering the survival analysis, it emerges the lack of the already mentioned crossing of the two curves observed in the first three-six months of the clinical trials with ICIs as monotherapy (Fig. 1b). In this case, the immunotherapy plus chemotherapy cohort demonstrated a superior anti-tumor effects for the entire duration of the follow-up [136].
Subsequent studies confirmed these initial findings [137], as also clearly shown in a recently published meta-analysis [138]. Indeed, Addeo et al. collected the data from several randomized clinical trials in which chemotherapy was administered with ICIs as first-line treatment for metastatic NSCLC patients. The Authors compared the PFS and OS of the chemotherapy alone group versus the chemotherapy plus immunotherapy arm. They found that in all considered clinical trials the combination of chemo/immunotherapy conferred an advantage in terms of OS and PFS compared to chemotherapy alone [138]. Apparently, no signs of HPD were detected in these trials. Taken together, these results suggest that adding a chemotherapeutic regimen to ICIs is a potential strategy to avoid the onset of HPD.

Although a certain mechanistic explanation of this phenomenon has not been provided yet and needs to be fully clarified, it is always possible to make some speculations based on what has been already reported in the literature. It is a long-held belief that chemotherapeutic drugs mainly exert a negative effect on the immune system, by killing effector cells or by suppressing/dampening their function. However, it is now well known that most of cytotoxic drugs have the ability to positively boost the immune response and that their immunestimulating ability represents an important component of their overall anti-tumor activity. Obviously, each drug may elicit the immune response in different ways, such as making cancer cells more recognizable for the immune attack (i.e. increased APCs maturation and antigen presentation), depleting immunosuppressive cells or directly stimulating cells with tumor-killing activity $[139,140]$.

In the majority of the clinical trials considered by Addeo et al. [138], the chemotherapeutic drugs utilized are platinum or its derivatives that belong to the alkylating agents, a class of drugs able to cross-link DNA strands, thereby inhibiting DNA synthesis, eventually inducing the apoptosis of cancer cells. Beyond their cytotoxic activity, this type of chemotherapy also profoundly
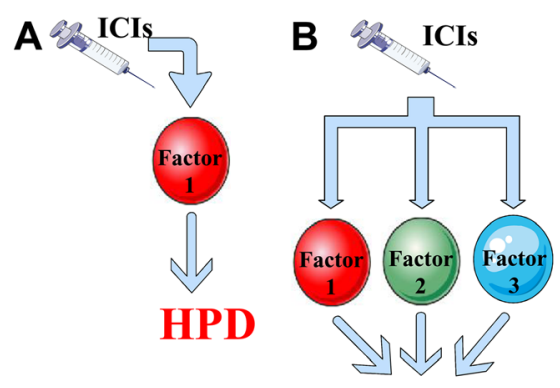

HPD

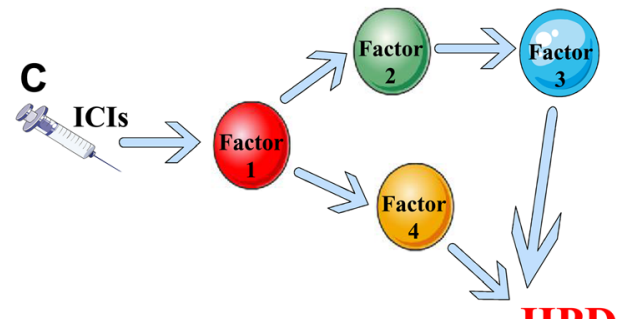

HPD

Fig. 2 Different possible models of HPD development. a HPD as a monofactorial process. $\mathbf{b}$ HPD as a multifactorial process. $\mathbf{c}$ HPD as a cascade of simultaneous events 
Table 6 Comparison between mechanisms only related to HPD or shared with PD

\begin{tabular}{|c|c|c|}
\hline \multicolumn{3}{|c|}{ IMMUNE-RELATED MECHANISMS } \\
\hline \multicolumn{3}{|c|}{ Innate immune cells } \\
\hline & PD & HPD \\
\hline NK cells & $\mathrm{N} / \mathrm{A}$ & $\mathrm{N} / \mathrm{A}$ \\
\hline Type 3 Innate Lymphoid cells (ILC3) & & 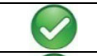 \\
\hline Dendritic cells (DCs) & 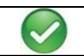 & 2 \\
\hline Antigen-presenting cells (APCs) & 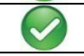 & 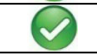 \\
\hline Monocytes & $\mathrm{N} / \mathrm{A}$ & $\mathrm{N} / \mathrm{A}$ \\
\hline \multicolumn{3}{|c|}{ Adaptive immune cells } \\
\hline & PD & HPD \\
\hline Tumor-infiltrating lymphocytes (TILs) & 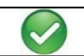 & 2 \\
\hline $\mathrm{CD8}^{+} \mathrm{T}$ cells & $Q$ & Q \\
\hline Regulatory $T$ cells & & D \\
\hline CD4 $^{+}$Foxp3-PD-1 ${ }^{\text {high }} T$ cells $\left(4 P D 1^{\text {hi }}\right)$ & ( & ( ) \\
\hline \multicolumn{3}{|c|}{ Role of the Fc domain } \\
\hline & PD & HPD \\
\hline PD-1 ${ }^{+}$cells and macrophages & & $\theta$ \\
\hline Fc $\gamma$ RIIb $^{+}$cells and macrophages & & ( ) \\
\hline \multicolumn{3}{|c|}{ TUMOR-RELATED MECHANISMS } \\
\hline & PD & HPD \\
\hline MDM2/MDM4 amplification & & 2 \\
\hline VEGFR2 polymorphisms & & Q \\
\hline KRAS and STK11 alterations & 2 & ( ) \\
\hline Tumor cell-intrinsic PD-1 expression & Q & D \\
\hline
\end{tabular}

HPD Hyperprogressive disease, PD Progressive disease, N/A Not assigned

impacts on the immune TME. After been damaged by chemotherapy, tumor cells start to expose calreticulin on their plasma membrane that, acting as "eat-me" signal, favors the phagocytosis of dying cells and cellular debris by APCs, in particular DCs. It should be noted that platinum does not induce calreticulin exposure, while some of its derivatives do. Moreover, platinum compounds induce neoplastic cell to release ATP, a molecule able to induce DCs recruitment and activation/ maturation, and High Mobility Group Box 1 (HMGB1) that triggers TLR4 on DCs leading to an enhanced activation and antigen presentation capacity. This type of chemotherapy can also directly act on DCs attenuating STAT6 signaling and determining a downregulation of PD-L2, thus reducing the immunosuppressive potential of these immune cells. All these mechanisms, that can be grouped together under the same cellular process defined "immunologic cell death" (ICD), concur to promote a more efficient and stronger tumor-antigen presentation to $\mathrm{T}$ cells [141-143]. In addition to ICD, platinum drugs can also sensitize cancer cells to $\mathrm{T}$ cell attack: first, making these cells more sensitive to granzyme-B-mediated killing and, second, by increasing MHC class I expression. Finally, some platinum derivatives, such as oxaliplatin, are able to reduce the number of MDSCs and their immunosuppressive properties [141-143] (Fig. 1c).

Collectively, these results suggest that even if a tumor is characterized by the presence of immune cells that potentially can trigger HPD upon ICIs treatment, the concomitant administration of standard chemotherapy should eliminate or, at least, constrain one or more factors able to induce HPD. Moreover, the ability of chemotherapy to abrogate HPD will be an extremely useful tool for scientists for better understanding HPD.

HPD or not HPD: that is the question

It is evident that HPD, at present, remains a quite elusive clinical problem. In this Review, we tried to summarize not only the mechanisms that are already demonstrated to be a cause of HPD but also those that we considered to be possibly linked to this phenomenon. 
Every single study discussed here represents a piece that fits in with a larger picture. However, since the study aimed at identifying the cellular and molecular origin of HPD is still at its infancy and the data at our disposition are very few, we cannot say for sure if only one of the proposed mechanisms can be sufficient to trigger HPD (Fig. 2a) or whether this detrimental outcome to ICI therapy requires the coexistence of two or more contributing factors (Fig. 2b). It is also possible to imagine a scenario in which the presence of one of the above-cited factors may constitute a conditio sine qua non for HPD development, initiating after interaction with ICIs a cascade of events able to negatively affect all the surrounding tumor microenvironment and promoting tumor growth, in a sort of domino effect (Fig. 2c). Therefore, a single factor might be not able per se to induce HPD but might need to be a part of an intricate network of concurrent causes and, based on the nature of this combination, it may trigger HPD or not.

Moreover, if we analyze what has been discussed before, we can notice that all the described mechanisms fall under two big groups: those promoting an exacerbation of the immune suppression, and those conferring to cancer cells an advantage in terms of survival/proliferation. However, these are some of those mechanisms that might increase tumor aggressiveness without any involvement of HPD. Therefore, one may rightly ask (i) whether these causative factors can be at the basis of both progression of the disease (PD) and HPD and (ii) if and how it is possible to discriminate between those causing the former or the latter. We believe that the central question is: "What is HPD?". This only partially answered question represents the central problem. To date, there is no consensus about the definition of HPD and, the dividing line between PD and HPD can be very thin and variable, depending on the criteria utilized for their definition. The comparison of data obtained from different research groups can be extremely challenging since the results may be influenced by the different classification systems. Moreover, as already said, if HPD is a multifactorial process, it might be very likely that a single mechanism may induce PD and only the combination of all those mechanisms together, like actors in the same play, might fully elicit HPD. However, based on what found in the literature, it is possible to make some speculations about how different mechanisms could be considered particularly related to HPD rather than in common with PD. Table 6 summarizes this attempt.

\section{Conclusions}

Since it cannot be denied that tumor progression unexpectedly speeds up in a fraction of patients during ICI immunotherapy, the understanding of this provocative phenomenon still remains an important challenge. The investigations aimed at elucidating the causes of HPD have important translational relevance and applications. Indeed, a better understanding of the mechanisms triggering HPD could lead to the identification of patients not to be treated with ICIs and to the development of novel approaches able to reverse this extremely negative clinical phenomenon.

\section{Abbreviations \\ ICls: Immune checkpoint inhibitors; CTLA-4: Cytotoxic T lymphocyte- associated protein 4; PD-1: Programmed cell death protein 1; PD-L1/ L2: Programmed cell death ligand 1 and 2; TME: Tumor microenvironment; JAK1/2: Janus kinases 1 and 2; HPD: Hyperprogressive disease; NSCLC: Non- small cell lung cancer; HNSCC: Head and Neck squamous cell carcinoma; AGC: Advanced gastric cancer; TGR: Tumor growth rate; TGK: Tumor growth kinetics; TTF: Time-to-treatment failure; ILCs: Innate lymphoid cells; DCs: Dendritic cells; TIDCs: Tumor-infiltrating dendritic cells; TAMs: Tumor- associated macrophages; FcRs: Immunoglobulin Fc receptors; MDM2/ 4: Murine double minute 2/4; IRF-8: Interferon regulatory factor 8; EGFR: Epidermal growth factor receptor; VEGFR2: Vascular endothelial growth factor receptor 2; ANGPT2: Angiopoietin-2; ANC: Absolute neutrophil count; STK11: Serine/threonine kinase 11}

\section{Acknowledgments}

Not applicable.

\section{Authors' contributions}

M.S. had the idea for the article and supervised the entire project; S.C., V.L.N. F.B., C.M. and F.A. performed the literature search; M.S. and S.C. drafted the manuscript; N.G., A.B., E.T., M.C.G. and L.S. critically revised the manuscript

The authors read and approved the final manuscript.

\section{Funding}

This work was supported by Fondazione AIRC per la Ricerca sul Cancro (Progetto MFAG 2017, Id.20554).

Availability of data and materials

Not applicable.

Ethics approval and consent to participate

Not applicable.

Consent for publication

Not applicable.

\section{Competing interests}

Marina Chiara Garassino declares personal financial interests with the following organizations: AstraZeneca, MSD International GmbH, BMS, Boehringer Ingelheim Italia S.p. A, Celgene, Eli Lilly, Ignyta, Incyte, Inivata, Medlmmune, Novartis, Pfizer, Roche, and Takeda; she also declares institutional financial interests with the following organizations: Eli Lilly, MSD, Pfizer (MISP), AstraZeneca, MSD International GmbH, BMS, Boehringer Ingelheim Italia S.p. A, Celgene, Ignyta, Incyte, Inivata, Medlmmune, Novartis, Pfizer, Roche, Takeda, Tiziana, and Foundation Medicine.

All the other authors declare that they have no potential competing interests.

\section{Author details}

'Dipartimento di Scienze Biomediche per la Salute, Università degli Studi di Milano, via Mangiagalli 31, 20133 Milan, Italy. ${ }^{2}$ Molecular Targets Unit, Department of Research, Fondazione IRCCS - Istituto Nazionale dei Tumori, via Amadeo 42, 20133 Milan, Italy. ${ }^{3}$ Thoracic Oncology Unit, Medical Oncology Department, Fondazione IRCCS Istituto Nazionale dei Tumori, via Venezian 1, 20133 Milan, Italy. 
Received: 18 June 2020 Accepted: 25 September 2020

Published online: 09 November 2020

\section{References}

1. Haanen JBAG, Robert C. Immune checkpoint inhibitors. Progress Tumor Res. 2015;42:55-66. https://doi.org/10.1159/000437178.

2. Topalian SL, Taube JM, Anders RA, Pardoll DM. Mechanism-driven biomarkers to guide immune checkpoint blockade in cancer therapy. Nat Rev Cancer. 2016;16:275-87. https://doi.org/10.1038/nrc.2016.36.

3. Pardoll D. Cancer and the immune system: basic concepts and targets for intervention. Semin Oncol. 2015;42:523-38. https://doi.org/10.1053/j. seminoncol.2015.05.003.

4. Wei SC, Duffy CR, Allison JP. Fundamental mechanisms of immune checkpoint blockade therapy. Cancer Discov. 2018:8:1069-86. https://doi. org/10.1158/2159-8290.CD-18-0367.

5. Ferris RL, Blumenschein G, Fayette J, Guigay J, Colevas AD, Licitra L, et al. Nivolumab for recurrent squamous-cell carcinoma of the head and neck. N Engl J Med. 2016;375:1856-67. https://doi.org/10.1056/NEJMoa1602252.

6. Larkin J, Chiarion-Sileni V, Gonzalez R, Grob JJ, Cowey CL, Lao CD, et al. Combined Nivolumab and Ipilimumab or Monotherapy in untreated melanoma. N Engl J Med. 2015;373:23-34. https://doi.org/10.1056/ NEJMoa1504030

7. Robert C, Schachter J, Long GV, Arance A, Grob JJ, Mortier L, et al. Pembrolizumab versus Ipilimumab in advanced melanoma. N Engl J Med. 2015;372:2521-32. https://doi.org/10.1056/NEJMoa1503093.

8. Robert C, Long GV, Brady B, Dutriaux C, Maio M, Mortier L, et al. Nivolumab in previously untreated melanoma without BRAF mutation. N Engl J Med. 2015;372:320-30. https://doi.org/10.1056/NEJMoa1412082.

9. Hamid O, Robert C, Daud A, Hodi FS, Hwu W-J, Kefford R, et al. Safety and tumor responses with lambrolizumab (anti-PD-1) in melanoma. N Engl J Med. 2013;369:134-44. https://doi.org/10.1056/NEJMoa1305133.

10. Topalian SL, Sznol M, McDermott DF, Kluger HM, Carvajal RD, Sharfman WH, et al. Survival, durable tumor remission, and long-term safety in patients with advanced melanoma receiving nivolumab. J Clin Oncol. 2014;32:102030. https://doi.org/10.1200/JCO.2013.53.0105.

11. Hodi FS, O'Day SJ, McDermott DF, Weber RW, Sosman JA, Haanen JB, et al. Improved survival with ipilimumab in patients with metastatic melanoma. N Engl J Med. 2010;363:711-23. https://doi.org/10.1056/NEJMoa1003466.

12. Borghaei $H$, Paz-Ares $L$, Horn L, Spigel DR, Steins $M$, Ready NE, et al. Nivolumab versus Docetaxel in advanced nonsquamous non-small-cell lung cancer. N Engl J Med. 2015;373:1627-39. https://doi.org/10.1056/ NEJMoa1507643.

13. Brahmer J, Reckamp KL, Baas P, Crinò L, Eberhardt WEE, Poddubskaya E, et al. Nivolumab versus Docetaxel in advanced squamous-cell non-small-cell lung cancer. N Engl J Med. 2015;373:123-35. https://doi.org/10.1056/ NEJMoa1504627.

14. Garon EB, Rizvi NA, Hui R, Leighl N, Balmanoukian AS, Eder JP, et al. Pembrolizumab for the treatment of non-small-cell lung cancer. N Engl J Med. 2015:372:2018-28. https://doi.org/10.1056/NEJMoa1501824.

15. Motzer RJ, Rini BI, McDermott DF, Redman BG, Kuzel TM, Harrison MR, et al. Nivolumab for metastatic renal cell carcinoma: results of a randomized phase II trial. J Clin Oncol. 2015;33:1430-7. https://doi.org/10.1200/JCO.2014. 59.0703.

16. Motzer RJ, Escudier B, McDermott DF, George S, Hammers HJ, Srinivas S, et al. Nivolumab versus Everolimus in advanced renal-cell carcinoma. N Engl J Med. 2015;373:1803-13. https://doi.org/10.1056/NEJMoa1510665.

17. Kaufman HL, Russell J, Hamid O, Bhatia S, Terheyden P, D'Angelo SP, et al. Avelumab in patients with chemotherapy-refractory metastatic Merkel cell carcinoma: a multicentre, single-group, open-label, phase 2 trial. Lancet Oncol. 2016;17:1374-85. https://doi.org/10.1016/S1470-2045(16)30364-3.

18. Balar AV, Galsky MD, Rosenberg JE, Powles T, Petrylak DP, Bellmunt J, et al. Atezolizumab as first-line treatment in cisplatin-ineligible patients with locally advanced and metastatic urothelial carcinoma: a single-arm, multicentre, phase 2 trial. Lancet. 2017;389:67-76. https://doi.org/10.1016/ S0140-6736(16)32455-2

19. Haslam A, Prasad V. Estimation of the percentage of US patients with cancer who are eligible for and respond to checkpoint inhibitor immunotherapy drugs. JAMA Netw Open. 2019;2:e192535. https://doi.org/ 10.1001/jamanetworkopen.2019.2535.
20. Sharma P, Hu-Lieskovan S, Wargo JA, Ribas A. Primary, adaptive, and acquired resistance to cancer immunotherapy. Cell. 2017;168:707-23. https://doi.org/10.1016/j.cell.2017.01.017.

21. Jenkins RW, Barbie DA, Flaherty KT. Mechanisms of resistance to immune checkpoint inhibitors. Br J Cancer. 2018;118:9-16. https://doi.org/10.1038/ bjc.2017.434.

22. Denis $M$, Duruisseaux $M$, Brevet $M$, Dumontet $C$. How can immune checkpoint inhibitors cause Hyperprogression in solid tumors? Front Immunol. 2020;11:492. https://doi.org/10.3389/fimmu.2020.00492.

23. Chubachi S, Yasuda H, Irie H, Fukunaga K, Naoki K, Soejima K, et al. A case of non-small cell lung cancer with possible "disease flare" on Nivolumab treatment. Case Rep Oncol Med. 2016;2016:1075641. https://doi.org/10. 1155/2016/1075641.

24. Champiat S, Dercle L, Ammari S, Massard C, Hollebecque A, Postel-Vinay S, et al. Hyperprogressive disease is a new pattern of progression in cancer patients treated by anti-PD-1/PD-L1. Clin Cancer Res. 2017;23:1920-8. https://doi.org/10.1158/1078-0432.CCR-16-1741.

25. Kim Y, Kim CH, Lee HY, Lee S-H, Kim HS, Lee S, et al. Comprehensive clinica and genetic characterization of Hyperprogression based on Volumetry in advanced non-small cell lung cancer treated with immune checkpoint inhibitor. J Thorac Oncol. 2019;14:1608-18. https://doi.org/10.1016/j.jtho. 2019.05.033.

26. Kamada T, Togashi Y, Tay C, Ha D, Sasaki A, Nakamura Y, et al. PD-1+ regulatory T cells amplified by PD-1 blockade promote hyperprogression of cancer. Proc Natl Acad Sci U S A. 2019;116:9999-10008. https://doi.org/10. 1073/pnas.1822001116

27. Kanjanapan Y, Day D, Wang L, Al-Sawaihey H, Abbas E, Namini A, et al. Hyperprogressive disease in early-phase immunotherapy trials: clinical predictors and association with immune-related toxicities. Cancer. 2019;125: 1341-9. https://doi.org/10.1002/cncr.31999.

28. Ferrara R, Mezquita L, Texier M, Lahmar J, Audigier-Valette C, Tessonnier L, et al. Hyperprogressive disease in patients with advanced non-small cell lung cancer treated with PD-1/PD-L1 inhibitors or with single-agent chemotherapy. JAMA Oncol. 2018:4:1543-52. https://doi.org/10.1001/ jamaoncol.2018.3676.

29. Lo Russo G, Moro M, Sommariva M, Cancila V, Boeri M, Centonze G, et al. Antibody-fc/FcR interaction on macrophages as a mechanism for Hyperprogressive disease in non-small cell lung cancer subsequent to PD-1/ PD-L1 blockade. Clin Cancer Res. 2019;25:989-99. https://doi.org/10.1158/ 1078-0432.CCR-18-1390.

30. Saâda-Bouzid E, Defaucheux C, Karabajakian A, Coloma VP, Servois V, Paoletti $X$, et al. Hyperprogression during anti-PD-1/PD-L1 therapy in patients with recurrent and/or metastatic head and neck squamous cell carcinoma. Ann Oncol. 2017;28:1605-11. https://doi.org/10.1093/annonc/ mdx178.

31. Kato S, Goodman A, Walavalkar V, Barkauskas DA, Sharabi A, Kurzrock R. Hyperprogressors after immunotherapy: analysis of genomic alterations associated with accelerated growth rate. Clin Cancer Res. 2017;23:4242-50. https://doi.org/10.1158/1078-0432.CCR-16-3133.

32. Frelaut M, Le Tourneau C, Borcoman E. Hyperprogression under immunotherapy. Int J Mol Sci. 2019. https://doi.org/10.3390/ijms20112674.

33. Wang $X$, Wang F, Zhong M, Yarden Y, Fu L. The biomarkers of hyperprogressive disease in PD-1/PD-L1 blockage therapy. Mol Cancer. 2020;19:81. https://doi.org/10.1186/s12943-020-01200-x.

34. Keir ME, Butte MJ, Freeman GJ, Sharpe AH. PD-1 and its ligands in tolerance and immunity. Annu Rev Immunol. 2008;26:677-704. https://doi.org/10. 1146/annurev.immunol.26.021607.090331.

35. Pardoll DM. The blockade of immune checkpoints in cancer immunotherapy. Nat Rev Cancer. 2012;12:252-64. https://doi.org/10.1038/nrc3239.

36. Pesce S, Greppi M, Grossi F, Del Zotto G, Moretta L, Sivori S, et al. PD/1-PDLs checkpoint: insight on the potential role of NK cells. Front Immunol. 2019:10:1242. https://doi.org/10.3389/fimmu.2019.01242.

37. Liu Y, Cheng Y, Xu Y, Wang Z, Du X, Li C, et al. Increased expression of programmed cell death protein 1 on NK cells inhibits NK-cell-mediated antitumor function and indicates poor prognosis in digestive cancers. Oncogene. 2017;36:6143-53. https://doi.org/10.1038/onc.2017.209.

38. Hsu J, Hodgins JJ, Marathe M, Nicolai CJ, Bourgeois-Daigneault M-C, Trevino TN, et al. Contribution of NK cells to immunotherapy mediated by PD-1/PD-L1 blockade. J Clin Invest. 2018;128:4654-68. https://doi.org/10.1172/JCl99317.

39. Solaymani-Mohammadi S, Lakhdari O, Minev I, Shenouda S, Frey BF, Billeskov $\mathrm{R}$, et al. Lack of the programmed death-1 receptor renders host 
susceptible to enteric microbial infection through impairing the production of the mucosal natural killer cell effector molecules. J Leukoc Biol. 2016;99: 475-82. https://doi.org/10.1189/jlb.4A0115-003RR.

40. Castellanos JG, Longman RS. The balance of power: innate lymphoid cells in tissue inflammation and repair. J Clin Invest. 2019;129:2640-50. https://doi. org/10.1172/JCl124617.

41. van Beek JJP, Martens AWJ, Bakdash G. Vries IJM de. Biomedicines: Innate Lymphoid Cells in Tumor Immunity; 2016. https://doi.org/10.3390/ biomedicines4010007.

42. Xiong D, Wang Y, Singavi AK, Mackinnon AC, George B, You M. Immunogenomic landscape contributes to Hyperprogressive disease after anti-PD-1 immunotherapy for cancer. iScience. 2018;9:258-77. https://doi. org/10.1016/j.isci.2018.10.021.

43. Vacca P, Pesce S, Greppi M, Fulcheri E, Munari E, Olive D, et al. PD-1 is expressed by and regulates human group 3 innate lymphoid cells in human decidua. Mucosal Immunol. 2019;12:624-31. https://doi.org/10.1038/ s41385-019-0141-9.

44. Tumino N, Martini S, Munari E, Scordamaglia F, Besi F, Mariotti FR, et al. Presence of innate lymphoid cells in pleural effusions of primary and metastatic tumors: functional analysis and expression of PD-1 receptor. Int J Cancer. 2019;145:1660-8. https://doi.org/10.1002/ijc.32262.

45. Kirchberger S, Royston DJ, Boulard O, Thornton E, Franchini F, Szabady RL, et al. Innate lymphoid cells sustain colon cancer through production of interleukin-22 in a mouse model. J Exp Med. 2013;210:917-31. https://doi. org/10.1084/jem.20122308.

46. Fung KY, Nguyen PM, Putoczki T. The expanding role of innate lymphoid cells and their T-cell counterparts in gastrointestinal cancers. Mol Immunol. 2019;110:48-56. https://doi.org/10.1016/j.molimm.2017.11.013.

47. Hepworth MR, Fung TC, Masur SH, Kelsen JR, MCConnell FM, Dubrot J, et al. Immune tolerance. Group 3 innate lymphoid cells mediate intestinal selection of commensal bacteria-specific CD4 ${ }^{+} \mathrm{T}$ cells. Science. 2015;348: 1031-5. https://doi.org/10.1126/science.aaa4812.

48. Versteven M, van den Bergh JMJ, Marcq E, Smits ELJ, van Tendeloo VFI, Hobo W, et al. Dendritic cells and programmed Death-1 blockade: a joint venture to combat cancer. Front Immunol. 2018;9:394. https://doi.org/10. 3389/fimmu.2018.00394.

49. Laoui $D$, Keirsse J, Morias $Y$, van Overmeire E, Geeraerts X, Elkrim Y, et al. The tumour microenvironment harbours ontogenically distinct dendritic cell populations with opposing effects on tumour immunity. Nat Commun. 2016;7:13720. https://doi.org/10.1038/ncomms13720.

50. Keirsse J, van Damme H, van Ginderachter JA, Laoui D. Exploiting tumorassociated dendritic cell heterogeneity for novel cancer therapies. J Leukoc Biol. 2017;102:317-24. https://doi.org/10.1189/jlb.4MR1116-466R.

51. Krempski J, Karyampudi L, Behrens MD, Erskine CL, Hartmann L, Dong H, et al. Tumor-infiltrating programmed death receptor-1+ dendritic cells mediate immune suppression in ovarian cancer. J Immunol. 2011;186:690513. https://doi.org/10.4049/jimmunol.1100274.

52. Karyampudi L, Lamichhane P, Krempski J, Kalli KR, Behrens MD, Vargas DM, et al. PD-1 blunts the function of ovarian tumor-infiltrating dendritic cells by inactivating NF-KB. Cancer Res. 2016;76:239-50. https://doi.org/10.1158/ 0008-5472.CAN-15-0748.

53. Lamichhane P, Karyampudi L, Shreeder B, Krempski J, Bahr D, Daum J, et al. IL10 release upon PD-1 blockade sustains immunosuppression in ovarian cancer. Cancer Res. 2017;77:6667-78. https://doi.org/10.1158/0008-5472. CAN-17-0740.

54. Zhao Y, Harrison DL, Song Y, Ji J, Huang J, Hui E. Antigen-presenting cellintrinsic PD-1 neutralizes PD-L1 in cis to attenuate PD-1 signaling in T cells. Cell Rep. 2018;24:379-390.e6. https://doi.org/10.1016/j.celrep.2018.06.054.

55. Olingy CE, Dinh HQ, Hedrick CC. Monocyte heterogeneity and functions in cancer. J Leukoc Biol. 2019;106:309-22. https://doi.org/10.1002/JLB.4RI0818-311R.

56. Said EA, Dupuy FP, Trautmann L, Zhang Y, Shi Y, El-Far M, et al, Programmed death-1-induced interleukin-10 production by monocytes impairs CD4+ T cell activation during HIV infection. Nat Med. 2010;16:452-9. https://doi.org/10.1038/nm.2106.

57. Zasada M, Lenart M, Rutkowska-Zapała M, Stec M, Durlak W, Grudzień A, et al. Analysis of PD-1 expression in the monocyte subsets from non-septic and septic preterm neonates. PLoS One. 2017;12:e0186819. https://doi.org/ 10.1371/journal.pone.0186819.

58. Ferreira da Mota NV, MKC B, Santos SS, Machado FR, Assuncao M, LCP A, et al. Immunophenotyping of monocytes during human sepsis shows impairment in antigen presentation: a shift toward nonclassical differentiation and Upregulation of FCYRi-receptor. Shock. 2018;50:293-300. https://doi.org/10.1097/SHK.0000000000001078.

59. Petrovas C, Casazza JP, Brenchley JM, Price DA, Gostick E, Adams WC, et al. PD-1 is a regulator of virus-specific CD8+ T cell survival in HIV infection. J Exp Med. 2006;203:2281-92. https://doi.org/10.1084/jem.20061496.

60. Ka MB, Gondois-Rey F, Capo C, Textoris J, Million M, Raoult D, et al. Imbalance of circulating monocyte subsets and PD-1 dysregulation in Q fever endocarditis: the role of IL-10 in PD-1 modulation. PLoS One. 2014;9: e107533. https://doi.org/10.1371/journal.pone.0107533.

61. Ma CJ, Ni L, Zhang Y, Zhang CL, Wu XY, Atia AN, et al. PD-1 negatively regulates interleukin-12 expression by limiting STAT-1 phosphorylation in monocytes/macrophages during chronic hepatitis C virus infection. Immunology. 2011;132:421-31. https://doi.org/10.1111/j.1365-2567.2010. 03382.x.

62. Zhang Y, Ma CJ, Ni L, Zhang CL, Wu XY, Kumaraguru U, et al. Cross-talk between programmed death-1 and suppressor of cytokine signaling-1 in inhibition of IL-12 production by monocytes/macrophages in hepatitis C virus infection. J Immunol. 2011;186:3093-103. https://doi.org/10.4049/ jimmunol.1002006.

63. Zhang Y, Zhou Y, Lou J, Li J, Bo L, Zhu K, et al. PD-L1 blockade improves survival in experimental sepsis by inhibiting lymphocyte apoptosis and reversing monocyte dysfunction. Crit Care. 2010;14:R220. https://doi.org/10. $1186 /$ cc9354.

64. Xia Q, Wei L, Zhang Y, Sheng J, Wu W, Zhang Y. Immune checkpoint receptors Tim-3 and PD-1 regulate monocyte and T lymphocyte function in septic patients. Mediators Inflamm. 2018;2018:1632902. https://doi.org/10. 1155/2018/1632902.

65. Hernandez C, Huebener P, Schwabe RF. Damage-associated molecular patterns in cancer: a double-edged sword. Oncogene. 2016;35:5931-41. https://doi.org/10.1038/onc.2016.104.

66. Escamilla-Tilch M, Filio-Rodríguez G, García-Rocha R, Mancilla-Herrera I, Mitchison NA, Ruiz-Pacheco JA, et al. The interplay between pathogenassociated and danger-associated molecular patterns: an inflammatory code in cancer? Immunol Cell Biol. 2013;91:601-10. https://doi.org/10.1038/icb.2013.58.

67. Mogensen TH. Pathogen recognition and inflammatory signaling in innate immune defenses. Clin Microbiol Rev. 2009;22:240-73. Table of Contents. https://doi.org/10.1128/CMR.00046-08.

68. Galli SJ, Borregaard N, Wynn TA. Phenotypic and functional plasticity of cells of innate immunity: macrophages, mast cells and neutrophils. Nat Immunol. 2011;12:1035-44. https://doi.org/10.1038/ni.2109.

69. Huang R-Y, Francois A, McGray AR, Miliotto A, Odunsi K. Compensatory upregulation of PD-1, LAG-3, and CTLA-4 limits the efficacy of single-agent checkpoint blockade in metastatic ovarian cancer. Oncoimmunology. 2017; 6:e1249561. https://doi.org/10.1080/2162402X.2016.1249561.

70. Kawakami Y, Ohta S, Sayem MA, Tsukamoto N, Yaguchi T. Immune-resistant mechanisms in cancer immunotherapy. Int J Clin Oncol. 2020;25:810-7. https://doi.org/10.1007/s10147-019-01611-x.

71. Shi H, Lan J, Yang J. Mechanisms of resistance to checkpoint blockade therapy. Adv Exp Med Biol. 2020;1248:83-117. https://doi.org/10.1007/978981-15-3266-5_5.

72. Koyama S, Akbay EA, Li YY, Aref AR, Skoulidis F, Herter-Sprie GS, et al. STK11/ LKB1 deficiency promotes neutrophil recruitment and Proinflammatory cytokine production to suppress T-cell activity in the lung tumor microenvironment. Cancer Res. 2016;76:999-1008. https://doi.org/10.1158/ 0008-5472.CAN-15-1439.

73. Sun Z, Fourcade J, Pagliano O, Chauvin J-M, Sander C, Kirkwood JM, et al. IL10 and PD-1 cooperate to limit the activity of tumor-specific CD8+ T cells. Cancer Res. 2015;75:1635-44. https://doi.org/10.1158/0008-5472.CAN-14-3016.

74. Togashi Y, Shitara K, Nishikawa H. Regulatory T cells in cancer immunosuppression - implications for anticancer therapy. Nat Rev Clin Oncol. 2019;16:356-71. https://doi.org/10.1038/s41571-019-0175-7.

75. Cai J, Wang D, Zhang G, Guo X. The role of PD-1/PD-L1 Axis in Treg development and function: implications for cancer immunotherapy. Onco Targets Ther. 2019;12:8437-45. https://doi.org/10.2147/OTT.S221340.

76. Zhang B, Chikuma S, Hori S, Fagarasan S, Honjo T. Nonoverlapping roles of PD-1 and FoxP3 in maintaining immune tolerance in a novel autoimmune pancreatitis mouse model. Proc Natl Acad Sci U S A. 2016;113:8490-5. https://doi.org/10.1073/pnas.1608873113.

77. Tay RE, Richardson EK, Toh HC. Revisiting the role of CD4+ T cells in cancer immunotherapy-new insights into old paradigms. Cancer Gene Ther. 2020. https://doi.org/10.1038/s41417-020-0183-x. 
78. Arasanz H, Zuazo M, Bocanegra A, Gato M, Martínez-Aguillo M, Morilla I, et al. Early detection of Hyperprogressive disease in non-small cell lung cancer by monitoring of systemic T cell dynamics. Cancers (Basel). 2020. https://doi.org/10.3390/cancers12020344.

79. Zappasodi R, Budhu S, Hellmann MD, Postow MA, Senbabaoglu Y, Manne S, et al. Non-conventional inhibitory CD4+Foxp3-PD-1 hi T cells as a biomarker of immune checkpoint blockade activity. Cancer Cell. 2018;33:1017-1032.e7. https://doi.org/10.1016/j.ccell.2018.05.009.

80. Thibult M-L, Mamessier E, Gertner-Dardenne J, Pastor S, Just-Landi S, Xerri L, et al. PD-1 is a novel regulator of human B-cell activation. Int Immunol. 2013;25:129-37. https://doi.org/10.1093/intimm/dxs098.

81. Soldevilla MM, Villanueva H, Martinez-Velez N, Meraviglia-Crivelli D, Alonso MM, Cebollero J, et al. Intratumoral injection of activated B lymphoblast in combination with PD-1 blockade induces systemic antitumor immunity with reduction of local and distal tumors. Oncoimmunology. 2018;7: e1450711. https://doi.org/10.1080/2162402X.2018.1450711.

82. Griss J, Bauer W, Wagner C, Simon M, Chen M, Grabmeier-Pfistershammer K, et al. B cells sustain inflammation and predict response to immune checkpoint blockade in human melanoma. Nat Commun. 2019;10:4186. https://doi.org/10.1038/s41467-019-12160-2.

83. Damsky W, Jilaveanu L, Turner N, Perry C, Zito C, Tomayko M, et al. B cell depletion or absence does not impede anti-tumor activity of PD-1 inhibitors. J Immunother Cancer. 2019;7:153. https://doi.org/10.1186/s40425019-0613-1.

84. Dasgupta S, Dasgupta S, Bandyopadhyay M. Regulatory B cells in infection, inflammation, and autoimmunity. Cell Immunol. 2020;352:104076. https:// doi.org/10.1016/j.cellimm.2020.104076.

85. Shah HB, Smith K, Wren JD, Webb CF, Ballard JD, Bourn RL, et al. Insights from analysis of human antigen-specific memory $B$ cell repertoires. Front Immunol. 2018;9:3064. https://doi.org/10.3389/fimmu.2018.03064.

86. Zhao K-L, Yang $X-J$, Jin H-Z, Zhao L, Hu J-L, Qin W-J. Double-edge role of B cells in tumor immunity: potential molecular mechanism. Curr Med Sci. 2019;39:685-9. https://doi.org/10.1007/s11596-019-2092-5.

87. Kang TH, Jung ST. Boosting therapeutic potency of antibodies by taming fc domain functions. Exp Mol Med. 2019;51:1-9. https://doi.org/10.1038/ s12276-019-0345-9.

88. Chiu ML, Goulet DR, Teplyakov A, Gilliland GL. Antibody structure and function: the basis for engineering therapeutics. Antibodies (Basel). 2019. https://doi.org/10.3390/antib8040055.

89. Vidarsson $G$, Dekkers $G$, Rispens T. IgG subclasses and allotypes: from structure to effector functions. Front Immunol. 2014;5:520. https://doi.org/ 10.3389/fimmu.2014.00520.

90. Yu J, Song Y, Tian W. How to select IgG subclasses in developing anti-tumor therapeutic antibodies. J Hematol Oncol. 2020;13:45. https://doi.org/10.1186/ s13045-020-00876-4.

91. Kretschmer A, Schwanbeck R, Valerius T, Rösner T. Antibody Isotypes for tumor immunotherapy. Transfus Med Hemother. 2017;44:320-6. https://doi. org/10.1159/000479240.

92. Chen $X$, Song $X$, Li K, Zhang T. FcyR-binding is an important functional attribute for immune checkpoint antibodies in cancer immunotherapy Front Immunol. 2019;10:292. https://doi.org/10.3389/fimmu.2019.00292.

93. Arlauckas SP, Garris CS, Kohler RH, Kitaoka M, Cuccarese MF, Yang KS, et al. In vivo imaging reveals a tumor-associated macrophage-mediated resistance pathway in anti-PD-1 therapy. Sci Transl Med. 2017. https://doi. org/10.1126/scitranslmed.aal3604.

94. Knorr DA, Ravetch JV. Immunotherapy and Hyperprogression: unwanted outcomes. Unclear Mechanism Clin Cancer Res. 2019;25:904-6. https://doi. org/10.1158/1078-0432.CCR-18-3144.

95. Swisher JFA, Haddad DA, McGrath AG, Boekhoudt GH, Feldman GM. IgG4 can induce an M2-like phenotype in human monocyte-derived macrophages through FcyRl. MAbs. 2014;6:1377-84. https://doi.org/10.4161/ 19420862.2014.975657

96. Tan BX, Liew HP, Chua JS, Ghadessy FJ, Tan YS, Lane DP, et al. Anatomy of Mdm2 and Mdm4 in evolution. J Mol Cell Biol. 2017;9:3-15. https://doi.org/ 10.1093/jmcb/mjx002.

97. Forschner A, Hilke F-J, Bonzheim I, Gschwind A, Demidov G, Amaral T, et al. MDM2, MDM4 and EGFR amplifications and Hyperprogression in metastatic Acral and mucosal melanoma. Cancers (Basel). 2020. https://doi.org/10.3390/ cancers12030540.

98. Mao S, Zhang J, Guo Y, Zhang Z, Wu Y, Zhang W, et al. Hyperprogression after anti-programmed cell death ligand-1 therapy in a patient with recurrent metastatic urothelial bladder carcinoma following first-line cisplatin-based chemotherapy: a case report. Drug Des Devel Ther. 2019;13: 291-300. https://doi.org/10.2147/DDDT.S181122.

99. Forschner A, Niessner H, Möller $Y$, Horak P, Fröhlich M, Warsow G, et al. Genomics of immunotherapy-associated Hyperprogressors-letter. Clin Cancer Res. 2017;23:6374-5. https://doi.org/10.1158/1078-0432.CCR-171480

100. Peng W, Liu C, Xu C, Lou Y, Chen J, Yang Y, et al. PD-1 blockade enhances T-cell migration to tumors by elevating IFN- $\gamma$ inducible chemokines. Cancer Res. 2012;72:5209-18. https://doi.org/10.1158/00085472.CAN-12-1187.

101. Schindler C, Levy DE, Decker T. JAK-STAT signaling: from interferons to cytokines. J Biol Chem. 2007;282:20059-63. https://doi.org/10.1074/jbc. R700016200.

102. Waight JD, Netherby C, Hensen ML, Miller A, Hu Q, Liu S, et al. Myeloidderived suppressor cell development is regulated by a STAT/IRF-8 axis. J Clin Invest. 2013;123:4464-78. https://doi.org/10.1172/JCl68189.

103. Zhao Y, Yu H, Hu W. The regulation of MDM2 oncogene and its impact on human cancers. Acta Biochim Biophys Sin Shanghai. 2014;46:180-9. https:// doi.org/10.1093/abbs/gmt147.

104. Fang DD, Tang Q, Kong Y, Wang Q, Gu J, Fang X, et al. MDM2 inhibitor APG-115 synergizes with PD-1 blockade through enhancing antitumor immunity in the tumor microenvironment. J Immunother Cancer. 2019;7: 327. https://doi.org/10.1186/s40425-019-0750-6.

105. Rajaram P, Chandra P, Ticku S, Pallavi BK, Rudresh KB, Mansabdar P. Epidermal growth factor receptor: role in human cancer. Indian J Dent Res. 2017;28:687-94. https://doi.org/10.4103/ijdr.IJDR_534_16.

106. Concha-Benavente F, Ferris RL. Reversing EGFR mediated Immunoescape by targeted monoclonal antibody therapy. Front Pharmacol. 2017:8:332. https:// doi.org/10.3389/fphar.2017.00332.

107. Lee CK, Man J, Lord S, Links M, Gebski V, Mok T, et al. Checkpoint inhibitors in metastatic EGFR-mutated non-small cell lung Cancer-a meta-analysis. J Thorac Oncol. 2017;12:403-7. https://doi.org/10.1016/j.jtho.2016.10.007.

108. Gainor JF, Shaw AT, Sequist LV, Fu X, Azzoli CG, Piotrowska Z, et al. EGFR mutations and ALK rearrangements are associated with low response rates to PD-1 pathway blockade in non-small cell lung cancer: a retrospective analysis. Clin Cancer Res. 2016;22:4585-93. https://doi.org/10.1158/10780432.CCR-15-3101.

109. Refae S, Gal J, Brest P, Giacchero D, Borchiellini D, Ebran N, et al. Hyperprogression under immune checkpoint inhibitor: a potential role for germinal immunogenetics. Sci Rep. 2020;10:3565. https://doi.org/10.1038/ s41598-020-60437-0

110. Meyers DE, Bryan PM, Banerji S, Morris DG. Targeting the PD-1/PD-L1 axis for the treatment of non-small-cell lung cancer. Curr Oncol. 2018;25:e32434. https://doi.org/10.3747/co.25.3976.

111. Shibuya M. Vascular endothelial growth factor (VEGF)-Receptor2: its biological functions, major signaling pathway, and specific ligand VEGF-E. Endothelium. 2006;13:63-9. https://doi.org/10.1080/10623320600697955.

112. Glubb DM, Cerri E, Giese A, Zhang W, Mirza O, Thompson EE, et al. Novel functional germline variants in the VEGF receptor 2 gene and their effect on gene expression and microvessel density in lung cancer. Clin Cancer Res. 2011;17:5257-67. https://doi.org/10.1158/1078-0432.CCR-11-0379.

113. Lian L, Li X-L, Xu M-D, Li X-M, Wu M-Y, Zhang Y, et al. VEGFR2 promotes tumorigenesis and metastasis in a pro-angiogenic-independent way in gastric cancer. BMC Cancer. 2019;19:183. https://doi.org/10.1186/s12885-019-5322-0.

114. Thurston G, Daly C. The complex role of angiopoietin-2 in the angiopoietintie signaling pathway. Cold Spring Harb Perspect Med. 2012;2:a006550. https://doi.org/10.1101/cshperspect.a006650.

115. Wu X, Giobbie-Hurder A, Liao X, Connelly C, Connolly EM, Li J, et al. Angiopoietin2 as a biomarker and target for immune checkpoint therapy. Cancer Immunol Res. 2017;5:17-28. https://doi.org/10.1158/2326-6066.CIR-16-0206.

116. Coffelt SB, Chen Y-Y, Muthana M, Welford AF, Tal AO, Scholz A, et al. Angiopoietin 2 stimulates TIE2-expressing monocytes to suppress $T$ cell activation and to promote regulatory $T$ cell expansion. J Immunol. 2011;186: 4183-90. https://doi.org/10.4049/jimmunol.1002802.

117. Sasaki A, Nakamura Y, Mishima S, Kawazoe A, Kuboki Y, Bando H, et al. Predictive factors for hyperprogressive disease during nivolumab as antiPD1 treatment in patients with advanced gastric cancer. Gastric Cancer. 2019;22:793-802. https://doi.org/10.1007/s10120-018-00922-8.

118. Yeh C-H, Bellon M, Nicot C. FBXW7: a critical tumor suppressor of human cancers. Mol Cancer. 2018;17:115. https://doi.org/10.1186/s12943-018-0857-2. 
119. Liu P, Wang Y, Li X. Targeting the untargetable KRAS in cancer therapy. Acta Pharm Sin B. 2019;9:871-9. https://doi.org/10.1016/j.apsb.2019.03.002.

120. Laderian B, Mundi P, Fojo T, Bates S. Emerging therapeutic implications of STK11 mutation: case series. Oncologist. 2020. https://doi.org/10.1634/ theoncologist.2019-0846.

121. Zhang H, Houghton AM. Good cops turn bad: the contribution of neutrophils to immune-checkpoint inhibitor treatment failures in cancer. Pharmacol Ther 2020;107662. https://doi.org/10.1016/j.pharmthera.2020.107662.

122. Howard R, Kanetsky PA, Egan KM. Exploring the prognostic value of the neutrophil-to-lymphocyte ratio in cancer. Sci Rep. 2019;9:19673. https://doi. org/10.1038/s41598-019-56218-z.

123. Sacdalan DB, Lucero JA, Sacdalan DL. Prognostic utility of baseline neutrophil-to-lymphocyte ratio in patients receiving immune checkpoint inhibitors: a review and meta-analysis. Onco Targets Ther. 2018;11:955-65. https://doi.org/10.2147/OTT.S153290.

124. Gürağaç A, Demirer $Z$. The neutrophil-to-lymphocyte ratio in clinical practice. Can Urol Assoc J. 2016;10:141. https://doi.org/10.5489/cuaj.3587.

125. Mezquita L, Auclin E, Ferrara R, Charrier M, Remon J, Planchard D, et al. Association of the Lung Immune Prognostic Index with immune checkpoint inhibitor outcomes in patients with advanced non-small cell lung cancer. JAMA Oncol. 2018:4:351-7. https://doi.org/10.1001/jamaoncol.2017.4771.

126. Banna GL, Di Quattro R, Malatino L, Fornarini G, Addeo A, Maruzzo M, et al. Neutrophil-to-lymphocyte ratio and lactate dehydrogenase as biomarkers for urothelial cancer treated with immunotherapy. Clin Transl Oncol. 2020. https://doi.org/10.1007/s12094-020-02337-3.

127. Ferrara R, Proto C, Lo Russo G, Signorelli D, Prelaj A, Galli G, et al. Abstract 4480: circulating and tumor associated neutrophil subtypes correlate with hyperprogressive disease (HPD) upon immunecheckpoint inhibitors (ICI) in advanced non-small cell lung cancer (aNSCLC) patients (pts) and in vivo models. In: Proceedings: AACR annual meeting 2020; April 27-28, 2020 and June 22-24. Philadelphia: American Association for Cancer Research; 08152020; 2020. p. 4480. https://doi.org/10.1158/1538-7445.AM2020-4480.

128. Du S, McCall N, Park K, Guan Q, Fontina P, Ertel A, et al. Blockade of tumorexpressed PD-1 promotes lung cancer growth. Oncoimmunology. 2018;7: e1408747. https://doi.org/10.1080/2162402X.2017.1408747.

129. Wang X, Yang X, Zhang C, Wang Y, Cheng T, Duan L, et al. Tumor cellintrinsic PD-1 receptor is a tumor suppressor and mediates resistance to PD-1 blockade therapy. Proc Natl Acad Sci U S A. 2020;117:6640-50. https:// doi.org/10.1073/pnas.1921445117.

130. Li H, Li X, Liu S, Guo L, Zhang B, Zhang J, et al. Programmed cell death-1 (PD-1) checkpoint blockade in combination with a mammalian target of rapamycin inhibitor restrains hepatocellular carcinoma growth induced by hepatoma cell-intrinsic PD-1. Hepatology. 2017;66:1920-33. https://doi.org/ 10.1002/hep.29360.

131. Kleffel S, Posch C, Barthel SR, Mueller H, Schlapbach C, Guenova E, et al. Melanoma cell-intrinsic PD-1 receptor functions promote tumor growth. Cell. 2015;162:1242-56. https://doi.org/10.1016/j.cell.2015.08.052.

132. Powles T, Durán I, van der Heijden MS, Loriot Y, Vogelzang NJ, de Giorgi U, et al. Atezolizumab versus chemotherapy in patients with platinum-treated locally advanced or metastatic urothelial carcinoma (IMvigor211): a multicentre, open-label, phase 3 randomised controlled trial. Lancet. 2018; 391:748-57. https://doi.org/10.1016/S0140-6736(17)33297-X.

133. Bellmunt J, de Wit $R$, Vaughn DJ, Fradet $Y$, Lee J-L, Fong $L$, et al, Pembrolizumab as second-line therapy for advanced Urothelial carcinoma. N Engl J Med. 2017;376:1015-26. https://doi.org/10.1056/NEJMoa1613683.

134. Schoenfeld AJ, Hellmann MD. Acquired resistance to immune checkpoint inhibitors. Cancer Cell. 2020;37:443-55. https://doi.org/10.1016/j.ccell.2020.03. 017.

135. Duan Q, Zhang $H$, Zheng J, Zhang L. Turning cold into hot: firing up the tumor microenvironment. Trends Cancer. 2020;6:605-18. https://doi.org/10 1016/j.trecan.2020.02.022

136. Langer CJ, Gadgeel SM, Borghaei H, Papadimitrakopoulou VA, Patnaik A, Powell SF, et al. Carboplatin and pemetrexed with or without pembrolizumab for advanced, non-squamous non-small-cell lung cancer: a randomised, phase 2 cohort of the open-label KEYNOTE-021 study. Lancet Oncol. 2016:17:1497-508. https://doi.org/10.1016/S1470-2045(16)30498-3.

137. Garassino MC, Gadgeel S, Esteban E, Felip E, Speranza G, Domine M, et al. Patient-reported outcomes following pembrolizumab or placebo plus pemetrexed and platinum in patients with previously untreated, metastatic, non-squamous non-small-cell lung cancer (KEYNOTE-189): a multicentre, double-blind, randomised, placebo-controlled, phase 3 trial. Lancet Oncol. 2020;21:387-97. https://doi.org/10.1016/S1470-2045(19)30801-0.

138. Addeo A, Banna GL, Metro G, Di Maio M. Chemotherapy in combination with immune checkpoint inhibitors for the first-line treatment of patients with advanced non-small cell lung cancer: a systematic review and literature-based meta-analysis. Front Oncol. 2019;9:264. https://doi.org/10. 3389/fonc.2019.00264.

139. Opzoomer JW, Sosnowska D, Anstee JE, Spicer JF, Arnold JN. Cytotoxic chemotherapy as an immune stimulus: a molecular perspective on turning up the immunological heat on cancer. Front Immunol. 2019;10:1654. https://doi.org/10.3389/fimmu.2019.01654.

140. Galluzzi L, Buqué A, Kepp O, Zitvogel L, Kroemer G. Immunological effects of conventional chemotherapy and targeted anticancer agents. Cancer Cell. 2015;28:690-714. https://doi.org/10.1016/j.ccell.2015.10.012.

141. Rébé C, Demontoux L, Pilot T, Ghiringhelli F. Platinum derivatives effects on anticancer immune response. Biomolecules. 2019. https://doi.org/10.3390/ biom10010013.

142. Leonetti A, Wever B, Mazzaschi G, Assaraf YG, Rolfo C, Quaini F, et al. Molecular basis and rationale for combining immune checkpoint inhibitors with chemotherapy in non-small cell lung cancer. Drug Resist Updat. 2019; 46:100644. https://doi.org/10.1016/j.drup.2019.100644.

143. Hato SV, Khong A, de Vries IJM, Lesterhuis WJ. Molecular pathways: the immunogenic effects of platinum-based chemotherapeutics. Clin Cancer Res. 2014;20:2831-7. https://doi.org/10.1158/1078-0432.CCR-13-3141.

\section{Publisher's Note}

Springer Nature remains neutral with regard to jurisdictional claims in published maps and institutional affiliations.

Ready to submit your research? Choose BMC and benefit from:

- fast, convenient online submission

- thorough peer review by experienced researchers in your field

- rapid publication on acceptance

- support for research data, including large and complex data types

- gold Open Access which fosters wider collaboration and increased citations

- maximum visibility for your research: over $100 \mathrm{M}$ website views per year

At BMC, research is always in progress.

Learn more biomedcentral.com/submissions 